Illinois State University

ISU ReD: Research and eData

Theses and Dissertations

4-24-2017

\title{
A Qualitative Investigation of Secondary General Education Teachers' Perspectives on their Involvement in Transition Services
}

Stephen M. Kwiatek

Illinois State University, smkwiatek@gmail.com

Follow this and additional works at: https://ir.library.illinoisstate.edu/etd

Part of the Special Education Administration Commons, and the Special Education and Teaching Commons

\section{Recommended Citation}

Kwiatek, Stephen M., "A Qualitative Investigation of Secondary General Education Teachers' Perspectives on their Involvement in Transition Services" (2017). Theses and Dissertations. 808.

https://ir.library.illinoisstate.edu/etd/808

This Thesis is brought to you for free and open access by ISU ReD: Research and eData. It has been accepted for inclusion in Theses and Dissertations by an authorized administrator of ISU ReD: Research and eData. For more information, please contact ISUReD@ilstu.edu. 


\title{
A QUALITATIVE INVESTIGATION OF SECONDARY GENERAL EDUCATION TEACHERS' PERSPECTIVES ON THEIR INVOLVEMENT IN TRANSITION SERVICES
}

\author{
Stephen M. Kwiatek
}

109 Pages

This exploratory qualitative study was designed to examine the perspectives of secondary general education teachers' involvement within the transition for all youth, including youth with disabilities. Youth with disabilities continue to find less success than peers without disabilities during postsecondary life. Research has examined special education teachers and transition professionals' roles within the transition process, but limited research has been conducted relating to general education teachers' roles. Qualitative data obtained through semi-structured interviews indicate the opportunity for more substantive involvement in transition planning for all students, including those with disabilities. Overall findings suggest that general educators have desired student outcomes for all students, expose students to postsecondary options and help them set goals, facilitate opportunities for students to develop needed skills for adult life, participate in IEP meetings, and communicate and collaborate. Implications for future research include special educators providing general education teachers with information and opportunities to engage in the transition process.

KEYWORDS: Transition, Secondary, Student, Disability 


\title{
A QUALITATIVE INVESTIGATION OF SECONDARY GENERAL EDUCATION TEACHERS’ PERSPECTIVES ON THEIR INVOLVEMENT IN TRANSITION SERVICES
}

STEPHEN M. KWIATEK

\author{
A Thesis Submitted in Partial \\ Fulfillment of the Requirements \\ for the Degree of \\ MASTER OF SCIENCE \\ Department of Special Education \\ ILLINOIS STATE UNIVERSITY
}


Copyright 2017 Stephen M. Kwiatek 


\section{A QUALITATIVE INVESTIGATION OF SECONDARY GENERAL EDUCATION TEACHERS’ PERSPECTIVES ON THEIR INVOLVEMENT IN TRANSITION SERVICES}

STEPHEN M. KWIATEK

COMMITTEE MEMBERS:

Debbie Shelden, Chair

Carrie Anna Courtad

Nicole M. Uphold 


\section{ACKNOWLEDGMENTS}

Without the support from my committee members, family, and friends, I would not have been able to complete this project. First, I cannot thank Debbie Shelden enough for her genuine caring, wisdom, encouragement, and guidance. The countless hours we have spent brainstorming and collaborating are times that I will never forget. From our coffee shop meetings to our on-campus discussions, I was blessed with the opportunity to learn from you. I am honored to have you as my thesis chair and mentor. You have played a critical role in my development as a student, professional, and as a person for which I will be forever grateful.

Next, I would like to thank my committee members Carrie Anna Courtad and Nicole Uphold. Your feedback and collaboration were crucial for this project. I am grateful for the opportunity to learn from each of my committee members and for their time and dedication.

Additionally, I would like to thank Aunt Michelle, Uncle Ron, my cousin Kara Woodshank, and the rest of my family for their continued support and belief in me. Lastly, I could not have made it this far without the support of my dear friends Amy Sipovic, Kristin Starks, and Rachel Gorenz-Johnson. I am grateful to every person who has helped me learn and grow throughout this project. Thank you.

S. M. K. 


\section{CONTENTS}

\section{Page}

ACKNOWLEDGMENTS

CONTENTS

ii

TABLES

V

CHAPTER I: INTRODUCTION AND STATEMENT OF PROBLEM

Search Procedures

Inclusionary Criteria

Additional Search Procedures

Postsecondary Outcomes for Youth with Disabilities

General Education Role in Transition

Statement of Problem and Research Question

CHAPTER II: REVIEW OF LITERATURE

Overview of Transition Legislation

Postsecondary Outcomes

Education

Employment

Independent Living

Evolution of Transition Practices

Perceptions of Roles and Responsibilities in Transition

Curriculum and Transition

Barriers to Effective Implementation of Transition Practices 
A Case for General Education's Involvement in Transition

Importance of Collaboration

Educational Settings for Youth with Disabilities

Gap in Research and Research Question

CHAPTER III: METHODOLOGY

Participants

Professional Background

Instrumentation

Procedures

Interview Process

Security Procedures

Data Analysis

Results

Desired Outcomes

$\begin{array}{ll}\text { Postsecondary Exploration } & 40\end{array}$

Developing Skills

Authentic Teaching of Skills

Participating in IEP Meetings

Communicating

Barriers

Summary 
$\begin{array}{ll}\text { Findings } & 83\end{array}$

$\begin{array}{ll}\text { Benefits } & 83\end{array}$

$\begin{array}{ll}\text { Challenges } & 92\end{array}$

$\begin{array}{ll}\text { Conclusions } & 94\end{array}$

$\begin{array}{ll}\text { Limitations } & 95\end{array}$

Implications for Future Research 96

$\begin{array}{ll}\text { Implications for Practice } & 97\end{array}$

$\begin{array}{ll}\text { REFERENCES } & 100\end{array}$

$\begin{array}{ll}\text { APPENDIX: INTERVIEW PROTOCOL } & 108\end{array}$ 


\section{TABLES}

Table

Page

1. Participant Information 


\section{CHAPTER I: INTRODUCTION AND STATEMENT OF PROBLEM}

Transition from high school to postsecondary settings is a significant phase of life. Following their exit from high school, students may enroll in college or trade schools, obtain employment, enroll in the military, find new living arrangements, and engage in new community activities. This transition period is an exciting yet daunting time for all students, including youth with disabilities. Hughes and Carter (2011) noted that many youth with disabilities are not achieving their maximum potential as they transition into adult life. This study examined the roles that general education teachers might assume during the transition process.

\section{Search Procedures}

In this review of scholarly literature, I addressed the evolution of the field of secondary transition services related to the identification of transition practices and responsibilities for implementing those practices. To conduct my search, I began by using Illinois State University's Library's website. Using the library's general search tool, I used the following search terms to identify articles from the databases: a) transition, b) secondary, c) student, d) disability. Then, I filtered to include only "peer reviewed" articles. Since I began my search in a broad fashion, multiple databases were included within my search: a) ERIC (EBSCOhost), b) ERIC, and c) PsycInfo (EBSCOhost).

\section{Inclusionary Criteria}

Because many articles met my initial search criteria, I used these keywords as inclusionary criteria to narrow my focus: a) perceptions, b) EBPs, and/or c) curriculum. I chose these terms to identify literature related to teachers' perceptions of their transition curriculum and the efficacy of its implementation. If a research article had any of the inclusionary terms in its abstract, I read the article. If an article I read did indeed relate to the inclusionary terms, I 
added it to the list of articles used for this literature review. If an article did not have the search terms and inclusionary criteria, I did not include the article in this review.

\section{Additional Search Procedures}

I found little current literature on teachers' perceptions of their use of transition practices. To increase the number of articles included within my review, I conducted a historical search of the included articles' reference lists using the same inclusionary terms with the included articles' reference lists. If an article had any of the inclusionary terms within its title, I read the article. If an article I read related to the given topics, I included the article for this review. From my search procedures, I found articles from these journals: a) Career Development for Exceptional Individuals, b) Teacher Education and Special Education, c) Journal of Intellectual Disability Research, d) Education and Training in Autism and Developmental Disabilities, e) Career Development and Transition for Exceptional Individuals, f) Journal of Vocational Rehabilitation, and g) Journal of Positive Behavior Interventions.

Next, I conducted a table of contents search in the journal Career Development and Transition for Exceptional Individuals. I searched for articles including my keywords and inclusionary criteria. I read the article's abstract. Then, I included the article if it was related to any of my keywords and inclusionary criteria.

\section{Postsecondary Outcomes for Youth with Disabilities}

The Individuals with Disabilities Education Improvement Act of 2004 (IDEA) defined transition as a "coordinated set of activities" for children with disabilities that ensures students learn from a "results-oriented" process. Also, IDEA (2004) requires that the child's strengths, preferences, and interests are included, and experiences and instruction are used to develop employment, postschool adult living, and daily living skills [(Sec. 602(34)(A)]. 
Even with this federal mandate, many transition-aged youth with disabilities still experience a lack of success in postsecondary settings (Bouck, 2012; Bouck \& Joshi, 2012; Newman, Wagner, Cameto, \& Knokey, et al., 2009; Newman, Wagner, Knokey, et al., 2011; Sanford, et al., 2011; Test, et al., 2009; Wagner, Newman, Cameto, Garza, \& Levine, 2005). Broad areas in which students with disabilities fall behind their peers without disabilities include postsecondary education, employment, and independent living. A lack of success in any of these outcome areas may in turn negatively affect a young adult's quality of life.

The National Longitudinal Transition Study-2 (NLTS2) examined postsecondary outcomes for youth with disabilities. Data were collected multiple times before and after youth with disabilities exited high school. Four years after high school, $45.0 \%$ of youth with disabilities had enrolled in postsecondary education (Newman, et al., 2009). At six years after high school, that increases to $55.0 \%$ (Sanford, et al., 2011) and at eight years, to $60.0 \%$ (Newman, Wagner, Knokey, et al., 2011). Despite these increases as time after high school increases, youth with disabilities still enroll in postsecondary education at a lower rate than their peers without disabilities (Newman, Wagner, Knokey et al., 2011).

Young adults with disabilities also have less positive outcomes in employment. Four years after leaving high school, $57.0 \%$ of youth with disabilities were employed (Newman, Wagner, Cameto, et al., 2009); that percentage increases slightly at eight years after high school, to $60.0 \%$ (Newman, Wagner, Knokey, et al., 2011). Even with modest gains, youth with disabilities were underemployed when compared to youth without disabilities by approximately six percent at the time of data collection (Newman, Wagner, Knokey, et al., 2011).

Independent living is another area in which youth with disabilities are not performing as well as their peers without disabilities. Newman et al. (2009) explained that residential 
independence is an important aspect for young adults with disabilities. Four years after high school, $25.0 \%$ of youth with disabilities lived independently (Newman, et al., 2009). This increased to $36.0 \%$ six years after high school (Sanford, et al., 2011) and $45.0 \%$ eight years after high school (Newman, Wagner, Knokey, et al., 2011).Within eight years of exiting high school, $44.7 \%$ of youth with disabilities lived independently at the time of data collection (Newman, Wagner, Knokey, et al., 2011). Only $59.0 \%$ of youth with disabilities had lived independently at some point since leaving high school (Newman, Wagner, Knokey, et al., 2011). Even with the gains made by youth with disabilities in education, employment, and independent living outcomes, youth with disabilities still lag behind peers without disabilities. Federal mandates have been one possible reason for transition gains experienced by youth with disabilities. However, there are other factors that may have also attributed to increased success.

\section{General Education Role in Transition}

The Individuals with Disabilities Education Act has a continued focus on accessing services in the general education curriculum. The 1997 amendments to IDEA mandated that general education teachers participate on IEP teams, including transition IEP teams. IDEA (1997) also required "That to the maximum extent appropriate children with disabilities, including children in public or private institutions or other care facilities, are educated with children who are nondisabled" [20 U.S.C. 1412(1)(5)]. Test, Bartholomew, and Bethune et al. (2015) "believe that all students are general education students first and that general educators need to know about EBP and predictors for their students with disabilities" (p. 269). Thomas and Dykes (2011) noted that postschool outcomes for all youth are less than desirable; therefore, there is a need for individuals who do not qualify for special education services to receive supports for transitioning into postsecondary settings. In order to support all youth, Thomas and 
Dykes explained that using Response to Intervention (RtI) to provide transition supports would benefit all students. To support youth without disabilities and because many students with disabilities' least restrictive environment is in fact within general education settings (Wagner, Newman, Cameto, Levine, \& Marder, 2003), the literature, then, suggests a substantive role for secondary general education teachers to assume in supporting the transition to adulthood for all youth.

\section{Statement of Problem and Research Question}

Even with these legal mandates, many transition-aged youth with disabilities continue to experience poor postsecondary outcomes (Benitez, et al., 2009; Blanchett, 2001; Bouck, 2012; Bouck \& Joshi, 2012; Carter, et al., 2013; Hughes \& Carter, 2011; Mazzotti \& Plotner, 2016; Mustian, Mazzotti, \& Test, 2012; Plotner, Mazzotti, Rose, \& Carlson-Britting, 2016; Plotner, Trach, \& Strauser, 2012; Test, et al., 2015; Test, Mazzotti, et al., 2009). Many researchers have examined various stakeholders' perceptions of transition practices for youth with disabilities, including vocational rehabilitation personnel (Mazzotti \& Plotner, 2016; Plotner, et al., 2012; Plotner, et al., 2016) and secondary special educators (Benitez, et al., 2009; Blanchett, 2001; Mazzotti \& Plotner, 2016; Plotner, et al., 2016). However, the scholarly research is lacking general educators' perceptions on their role for fostering postsecondary success.

Morningstar, Bassett, Kochlar-Bryant, Cashman, and Wehmeyer (2012) wrote "If we are to improve postsecondary outcomes for all youth, educational reform efforts must begin with the coordinated engagement and active participation of general and special secondary educators" ( $p$. 113). Thomas and Dykes (2011) also suggested that successful transition services can be promoted by general educators. Thomas and Dykes explained that all educators need training to 
implement transition practices effectively. Morningstar, et al. and Thomas and Dykes suggested including general education teachers in the discussion of implementing transition practices.

The need to examine general education teachers' roles in the transition process is further validated by data on educational settings. According to the National Center for Education Statistics (NCES) (2016), $61.2 \%$ of all youth with disabilities spend $80.0 \%$ or more of their day in general education settings. On average, youth with disabilities in the NLTS2 earned 16.7 credits in general education settings and earned 6.0 credits in special education settings, earning an average of $72.0 \%$ of their credits in general education settings (Newman, Wagner, Huang, et al., 2011). Furthermore, $28.0 \%$ of all youth with disabilities spent their entire school day within general education settings (Newman, Wagner, Huang, et al. (2011). General education teachers may provide new perspectives and supports that could possibly increase the likelihood of all students, including those with disabilities, finding postsecondary success. Therefore, secondary general education teachers will be the focus of this study.

Clearly general education teachers have potential to affect the implementation of transition practices. Research on general secondary educators' perceptions related to their involvement in the transition process is needed. While limited research has been conducted on special education teachers' and transition personnel's perspectives on roles and responsibilities related to implementing transition services (Blanchett, 2001; Benitez, et al., 2009; Mazzotti \& Plotner, 2016; Plotner, et al., 2016), I found no research focused solely on perceptions of general education teachers' roles.

Lazaroff (2013) did include general educators among a variety of professionals in his study. Lazaroff found differences in staff members' opinions, including general education teachers' perceptions, of their schools' transition process. He found some general educators 
provide supports for individualized transition opportunities. Other general educators mentioned school-wide supports available to all students, not opportunities tailored to individual youths' needs or postschool outcomes. Additionally, no research was found on the secondary general educators' involvement in transition. Therefore, the purpose of this study is to examine general educators' perceptions of how they support all youth, including those with disabilities, for adult life. General education teachers are valuable members of the IEP team who can offer a unique perspective on the progress youth with disabilities are making within inclusive settings. Additionally, general educators can provide suggestions that youth will need to reach their postsecondary goals. In order to examine the important perceptions of general education teachers related to transition services provided to youth as they prepare for adult life, the following research question will be addressed:

1. How do secondary education teachers describe their work related to supporting outcomes for youth with and without disabilities? 


\section{CHAPTER II: REVIEW OF LITERATURE}

The proposed study will be an examination of the general education teachers' perceptions of their role in supporting transition outcomes and implementing transition EBPs. In this literature review, I first present an overview of transition. Next, I review the literature related to these topics: a) postsecondary outcomes b) evolution of transition practices, c) perceptions of roles and responsibilities in transition, d) a case for general education's involvement in transition, and e) research gap and research question.

\section{Overview of Transition Legislation}

IDEA frames the transition process as "results-oriented." (IDEA, 2004). As of 2004, the federal definition of transition services is:

The term "transition services" means a coordinated set of activities for a child with a disability that is designed to be within a results-oriented process, that is focused on improving the academic and functional achievement of the child with a disability to facilitate the child's movement from school to postschool activities, including postsecondary education; vocational education; integrated employment (including supported employment); continuing and adult education; adult services; independent living or community participation; and [602(34)(A)] is based on the individual child's needs, taking into account the child's strengths, preferences and interests [602(34)(B)].

The current legislative definition and requirements stem from an evolution of transition related policy beginning over twenty-five years ago. Due to the lack of success experienced by individuals with disabilities, reforms and initiatives were created to enhance the likelihood that transition-aged youth would achieve postsecondary success. Transition as a required component of an IEP was first included in IDEA in the 1990 amendments. At that time, IDEA required the 
implementation of transition services for youth with disabilities to include an individualized transition plan as a part of a student's IEP no later than age 16. Individual transition plans were created to include a coordinated set of activities that would help students find successful postschool outcomes in independent living, vocational training, and educational experiences. Interagency collaboration was also called for by the 1990 amendments.

Seven years later, the 1997 amendments further clarified the intent of secondary transition services. These amendments included changes to better facilitate postsecondary outcomes for youth with disabilities. Transition services and course of study were now to be planned and implemented by age 14, and additional clarification on the nature of transition activities was provided. As Kohler and Field (2003) described the 1997 amendments, "For the first time, federal policy communicated that the content of a student's education should be focused on his or her postschool aspirations" (p. 174). The 1997 amendments called for each student's choices, wants, and needs to be reflected in his or her postsecondary goals and listing adult outcome areas (education and training, employment, adult living, and community involvement). Also, IDEA (1997) required IEP teams to extend transition services beginning at age 14. Lastly, transition services now included related services, including vocational education. The Individuals with Disabilities Education Improvement Act of 2004 (IDEA, 2004) continued to define transition as a "coordinated set of activities" for children with disabilities but revised "outcome oriented process" to "results-oriented process."

IDEA (1990) was amended in part to help students with disabilities prepare for postsecondary education, employment, and living opportunities. IDEA (2004) holds local education agencies accountable to help make certain students with disabilities have the skills, knowledge, and plans necessary to live as independently as possible and become self-sufficient, 
respected, and contributing members of society. The 2004 amendments further emphasized the central role of age-appropriate transition assessment in the transition planning process.

The role of schools in promoting adult outcomes was also the focus of the School to Work Opportunity Act (STWOA) of 1994. Though in this case the legislation addressed outcomes for all students, not only those with disabilities. The purpose of the STWOA was to help students learn vital skills needed for adult life. Three major components were implemented to facilitate the successful transition to career for all youth: a) school-based learning, b) workbased learning, and c) connecting activities. School-based learning included students receiving academic and vocational instruction during and after high school in order to obtain the specific skills related to a certain occupation. The work-based learning component allowed students to learn in the work environment from a mentor, and the work experience directly related to the students' education. To ensure that there was a smooth transition from school to work, a team of individuals worked together, including employers, postsecondary personnel, and individuals able to provide technical assistance. The school-based learning component was created for students to achieve the same state-required academic standards in order to prepare them for adult life. This program was designed for all students to receive a high school diploma, GED, or alternative diploma for youth with disabilities, if appropriate, and a skill certificate. This program was a general education initiative to provide transition services for all students. It emphasized the role that general educators could assist in facilitating postsecondary success.

\section{Postsecondary Outcomes}

Federal mandates have positively affected but not maximized success for transition-aged youth with disabilities. In fact, despite gains in outcomes since the 1990s, many youth with disabilities are still unsuccessful in postsecondary settings (Newman, et., al., 2009; Newman, 
Wagner, Knokey, et al., 2011; Sanford, et al., 2011; Test, Mazzotti, et al., 2009; Wagner, et al., 2005). Transition-aged youth with disabilities continue to experience a lack of success that could affect their quality of life. General outcome areas in which students with disabilities fall behind their peers without disabilities are postsecondary education, employment, and independent living.

Researchers have documented and discussed in great length the outcomes of transitionaged youth with disabilities (Benitez, et al., 2009; Blanchett, 2001; Bouck, 2012; Bouck \& Joshi, 2012; Carter, et al., 2013; Hughes \& Carter, 2011; Mazzotti \& Plotner, 2016; Mustian, et al., 2012; Plotner, et al., 2012; Plotner, et al., 2016; Test, et al., 2015; Test, Mazzotti, et al., 2009). Although researchers have conducted many state and national studies relating to postsecondary outcomes for youth with disabilities, Carter et al. (2013) suggested we have not adequately analyzed numerous existing databases, analysis that could lead to more understanding of the experiences of youth and young adults with and without disabilities.

\section{Education}

Postsecondary education is an option many transition-aged youth consider. According to the U.S. Department of Commerce U.S. Census Bureau (2002), an individual who has earned a college degree will earn $\$ 1$ million more than a person who has earned a high school diploma (as cited in Newman, Wagner, Knokey, et al., 2011). Transition-aged youth with disabilities from all disability categories attended postsecondary education (Newman, Wagner, Knokey, et al., 2011).

The NLTS2 found that at four and eight years after leaving high school, $45.0 \%$ to $60.0 \%$ of youth with disabilities had been enrolled at some point in a postsecondary school (Newman, et al., 2009; Newman, Wagner, Knokey et al., 2011; Sanford, et al., 2011). Upon entering 
postsecondary educational settings, $63.0 \%$ of youth with disabilities did not self-identify as having a disability (Newman, Wagner, Knokey, et al., 2011). For youth with disabilities to receive reasonable accommodations in postsecondary educational settings, they are required to disclose their disability to the school. However, only $19.0 \%$ of youth with disabilities enrolled in postsecondary settings utilized their disability-specific accommodations (Newman, Wagner, Knokey, et al., 2011). Of those who enrolled in postsecondary education, attendees enrolled in a two-year college earned 23 credit hours on average, and those who attended a four-year college earned 71 credit hours (Newman, Wagner, Knokey, et al., 2011).

Eight years after exiting high school, $90.0 \%$ of participants enrolled in postsecondary settings were working towards completion of their degrees or certificates (Newman, Wagner, Knokey, et al., 2011). Reasons for not completing degrees and certificates were: a) change of schools (11.2\%), b) expense (20.5\%), c) schedule conflicts (5.0\%), d) poor grades $(8.9 \%)$, e) lack of school enjoyment (7.8\%), f) work-related reason $(10.5 \%)$, g) illness or disability $(2.0 \%)$, h) family reasons $(10.0 \%)$, or i) other reasons $(32.8 \%)$.

Overall, youth with disabilities graduated or finished their educational program at any postsecondary school at a lower rate than youth without disabilities $(40.7 \%$ and $52.4 \%$, respectively) (Newman, Wagner, Knokey, et al., 2011). Youth with disabilities (41.3\%) completed community college at a higher rate than did youth from the general population (22.4\%) eight years after exiting high school (Newman, Wagner, Knokey, et al., 2011). However, youth with disabilities completed their programs at lower rates than youth from the general population at vocational, business, or technical schools (7.8\% difference) and at 4-year colleges (17.0\% difference) (Newman, Wagner, Knokey, et al., 2011). 


\section{Employment}

Newman, Wagner, Knokey, et al. (2011) explained that employment is considered a main part of many adults' lives because work provides them with a social network, a feeling of worth, and a feeling of being productive members of society. Research suggests that, although youth with disabilities have more success with postsecondary employment outcomes than with postsecondary education outcomes, they still lag behind their peers without disabilities in the duration of their employment (Newman, et al., 2009). According to Newman, Wagner, Knokey, et al. (2011) and Sanford, et al. (2011), youth with disabilities averaged slightly higher rates of employment than youth without disabilities after six and eight years after exiting high school during the time of their interviews. While that is growth for youth with disabilities in relation to their employment outcomes, the average wage for employment of youth with disabilities still has room for improvement. Four years after exiting high school, youth with disabilities averaged $\$ 8.20$ per hour, and the general population's average earnings were $\$ 9.20$ per hour (Newman, et al., 2009). Six years after exiting high school, youth with disabilities averaged $\$ 9.40$ per hour, and the average general population's average wage was $\$ 13.20$ per hour (Sanford, et al., 2011). The difference between the amount of money youths with and without disabilities earned lessened after being out of high school for eight years. Youth with disabilities earned an average wage of $\$ 10.40$ per hour, while the general population averaged $\$ 11.40$ per hour (Newman, Wagner, Knokey, et al., 2011).

The majority of youth earned more than minimum wage four and eight years after exiting school (Newman, et al., 2009; Newman, Wagner, Knokey, et al., 2011). Although Sanford et al. (2011) did not specifically mention minimum wage based on the entire population of youth with 
disabilities, they noted that minimum wage ranged from $\$ 5.15$ per hour up to $\$ 7.73$ per hour, and the average hourly wage reported was $\$ 9.40$ per hour.

Four years after exiting high school, the average youth with disabilities had held two or three jobs (Newman, et al., 2009). Within the eight years after leaving high school, $91.0 \%$ of youth with disabilities had held an average of four jobs (Newman, Wagner, Knokey, et al., 2011). Also, respondents of the NLTS2 who were employed full-time typically earned more money than the respondents who worked part-time (Newman, et al., 2009; Newman, Wagner, Knokey, et al., 2011). Within four years of exiting high school, only about $19.0 \%$ of youth with disabilities reported their disabilities to their employers; furthermore, only three percent received employment accommodations (Newman, et al., 2009). Within eight years of leaving high school, only $26.0 \%$ of working adults with disabilities had employers who knew of their disabilities

(Newman, Wagner, Knokey, et al., 2011). Furthermore, only seven percent received accommodations at work. Regardless of positive feelings reported about their jobs, $53 \%$ of adults with disabilities quit their last job (Newman, Wagner, Knokey, et al., 2011).

\section{Independent Living}

Financial and residential independence are markers of success for young adults transitioning into adulthood (Newman, Wagner, Knokey, et al., 2011). Within four years of exiting high school, approximately $25.0 \%$ of youth with disabilities lived independently, which was less than the average $28.0 \%$ of youth without disabilities (Newman, et al., 2009). An even larger gap existed between the percentage of youth with disabilities (35.7\%) who lived independently and youth without disabilities (44.2\%) (Sanford, et al., 2011). After eight years of exiting high school, $44.7 \%$ of youth with disabilities and $59.0 \%$ of youth without disabilities lived independently (Newman, Wagner, Knokey, et al., 2011). Twenty-seven percent of 
individuals with disabilities had not lived independently since exiting high school (Newman, Wagner, Knokey, et al., 2011). Independent living for the participants could be living on their own, with a spouse/partner, or roommate (Newman, Wagner, Knokey, et al., 2011). More youth with disabilities than youth without disabilities lived semi-dependently four years after high school. Individuals with disabilities are considered to live semi-dependently if they live in a college dormitory, military housing, or a group home (Newman, Wagner, Knokey, et al., 2011). Nonetheless, youth without disabilities were more likely to live semi-dependently than youth with disabilities six and eight years after exiting high school (Newman, et al., 2009; Newman, Wagner, Knokey, et al., 2011; Sanford, et al., 2011).

When asked about their living arrangements, young adults with disabilities rated their satisfaction four years after leaving high school as follows: $58.0 \%$ were satisfied, $17.0 \%$ would prefer living elsewhere, and 25.0\% were ambivalent (Newman, et al., 2009). After eight years of exiting school, participants reported their satisfaction about their living arrangements: 69.0\% satisfied, $24.0 \%$ would prefer living elsewhere, and $7.0 \%$ were ambivalent (Newman, Wagner, Knokey, et al., 2011). Overall, youth with disabilities were satisfied with their living arrangements. However, $31.0 \%$ and $42.0 \%$ of youth with disabilities did not rate that they were satisfied with their living arrangements, which could be cause for concern.

Only $10.0 \%$ to $16.8 \%$ of individuals with disabilities were married or in a marriage-like relationship between four to eight years after leaving high school (Newman, et al., 2009; Newman, Wagner, Knokey, et al., 2011; Sanford, et al., 2011). Four years after leaving high school, the average income of youth with disabilities was reported to be $\$ 25,000$ or less annually (Newman, et al., 2009). On average, $74.0 \%$ of individuals with disabilities or couples made an 
income of $\$ 25,000$ or less annually eight years after exiting high school (Newman, Wagner, Knokey, et al., 2011).

Summary. Hughes and Carter (2011) suggested that future education reforms should hold high schools responsible for ensuring that all students with disabilities have an "identified postschool placement—postsecondary education or employment—before school exit.” (p. 179). Teachers are required to ensure students are prepared with the necessary skills for postsecondary settings. Yet, based on the NLTS2 data, many youth with disabilities preparing to transition to adult life continue to be unsuccessful.

\section{Evolution of Transition Practices}

The field of transition has made great strides in supporting educators and researchers by identifying EBPs to support transition-aged youth with disabilities. However, it is interesting to note that some best practices have not changed since Kohler's (1993) publication on substantiated or implied best practices. For example, vocational training, interagency collaboration, and employability skills training were practices that are now supported as EBPs that are effective for promoting postsecondary success (Kohler, 1993; Landmark, Ju, \& Zhang, 2010; Test, Fowler, et al., 2009 Test, Mazzotti, et al., 2009). Although these identified practices have evolved in both title and the nature of research to substantiate them (Landmark, et al., 2010;

Test, Fowler, et al., 2009; Test, Mazzotti, et al., 2009), Kohler's (1993) suggestions on best practices are still respected and found valid today.

While there are similarities between the specific skills suggested as practices for promoting postsecondary success beginning with Kohler's (1993) article, there are also differences that exist within the literature. For example, Landmark et al. (2010) found research 
that supported the use of paid and unpaid work experiences to support postsecondary outcomes, though Kohler's (1993) list included only paid work.

Another change occurred due to IDEA's (2004) accountability requirement related to youth with disabilities' least restrictive environment. Though the principle of least restriction environment has been central to special education legislation since the original Education for All Handicapped Children Act of 1975, IDEA (2004) further clarified that educational placement must include consideration for access to general education settings. Kohler's (1993) article referenced academic skill training, which, at that time, was not described in a particular setting. However, a currently identified research-based practice is teaching students with disabilities in a general education setting to the greatest extent possible. Therefore, this could be a difference

due to legislation between Kohler's (1993) best practices and today's best practices (Landmark, et al., 2010).

Kohler's (1993) list of substantiated and implied transition practices have evolved since she reviewed the scholarly literature. However, it is interesting to note that many of Kohler's identified transition practices are still relevant today. Her list of transition practices have allowed researchers to further analyze, evaluate, refine transition practices, and create, operationally define a list of transition evidence-based predictors.

\section{Perceptions of Roles and Responsibilities in Transition}

Transition-related roles and responsibilities should be different across school personnel roles (Li, Bassett, \& Hutchinson, 2009). In order to understand what transition professionals see as their roles and responsibilities, along with the competencies needed to support transitioning youth, researchers have conducted numerous studies, including some published last year. According to Blanchett (2001), “the significance of identifying and establishing professional 
competencies and guidelines for the preparation and certification of special educators has been the point of convergence in the professional literature" (p. 4). Blanchett surveyed special education teachers about the competencies needed by special and general educators to work with transition-aged youth. Over half of respondents rated all transition competencies as more important. However, almost half of Blanchett's (2001) participants felt varying degrees of unpreparedness as they delivered transition services.

Blanchett was not alone in finding transition professionals felt unprepared to deliver transition services effectively (Benitez, et al., 2009; Mazzotti \& Plotner, 2016; Plotner, et al., 2016). Mazzotti and Plotner (2016) found transition service providers had limited access to, training with, and preparation for transition EBPs. Plotner, et al. (2012) studied the perceptional differences in access to transition EBPs between special educators and direct-service professionals. They found over $60.0 \%$ of participants strongly disagreed that they gained transition EBP knowledge from college. To learn about transition EBPs, special educators (48.0\%) and district-service transition professionals (about 60.0\%) learned about EBPs by reading professional journals.

Additionally, Benitez, et al. (2009) noted that special education teachers felt unprepared to properly support students related to their transition needs. They found special educators felt most confident with transition planning. The mean ratings ranged from 3.01 to 3.24 on a fourpoint Likert-type scale. Overall, professionals working with transition-aged youth with disabilities felt somewhat prepared (mean is 2.69). Li, et al. (2009) found that both special educators (mean is 4.10 out of 5.0) and transition coordinators rated themselves highly (4.28 out of 5.0) with their involvement of transition planning. Li et al.'s participants rated themselves slightly above average involvement in transition assessment and transition instruction. However, 
their participants rated themselves as below average involvement in interagency collaboration and job development, and transition coordinators rated themselves with much higher involvement in both of these aspects. The perceived responsibilities and levels of involvement and engagement differ depending upon the professionals' given role (Li, et al., 2009).

\section{Summary}

Several studies related to transition competencies suggest that vocational rehabilitation counselors and secondary special education teachers feel underprepared to deliver transition services effectively. Only one study examined general education teachers' role. That study, however, predates much of the work in identifying EBPs and other transition practices. Furthermore, in that study only special education teachers participated; general education teachers' perceptions of their own role in transition was not examined. Special educators described their perceptions of general education teachers' roles in transition.

\section{Curriculum and Transition}

Teachers teach both academic and functional skills. This is true for students with and without disabilities. According to the Illinois State Board of Education (ISBE, 2012), students require at least one year of education in art, music, foreign language, or vocational education. The vocational education option is one example of a functional curriculum from which all students can learn. Bouck and Joshi (2012) described the details of a functional curriculum to include "functional skills and applications of core subject areas (academics), vocational education, community access, daily living, financial, independent living, transportation, social/relationships, and self-determination" (2012, p. 140).

Teachers also teach using academic curricula. Teachers who use academic curricula are using "standards-based" curricula like the Common Core State Standards (Bouck, 2012, p. 
1176). Some researchers support the use of an academic curriculum for students (McLeskey, Landers, Hoppey, \& Williamson, 2011; Shifrer, Callahan, \& Muller, 2013).

Both functional and academic curricula have their benefits. Functional curricula can be used to teach students, time-management, self-advocacy, and self-determination skills (Bouck, 2012; Bouck and Joshi, 2012; Carter, Lane, Pierson, \& Glaeser, 2006). Researchers have explained that academic and standards-based classes benefit students with disabilities because they have an opportunity to be included in general education settings (McLeskey, et al., 2011; Shifrer, et al., 2013) With varying perspectives on which curriculum is best for students with disabilities, there does not appear to be one correct answer. Nonetheless, both types of curriculum have aspects that benefit transitioning students with disabilities with their postschool outcomes.

Students with disabilities take an average of $60.2 \%$ of their classes in general education settings (Wagner, Newman, Cameto, Levine, 2003). On average, over one-third of students in general education classes $(36.6 \%)$ has a disability. Approximately $66.0 \%$ of teachers rated their perceptions on youth with disabilities included in general education classes as very appropriate, and $25.6 \%$ of teachers rated their perceptions as somewhat appropriate (Wagner, et al., 2003). Therefore, a majority of general education teachers reported that they believe it is appropriate for youth with disabilities to learn in general education settings (Wagner, Newman, et al., 2003). Within academic classes, general education teachers incorporate life skills materials for the whole class (68.1\%) and for youth with disabilities (68.3\%). Within general education settings, youth with disabilities use life skills materials in math and science classes, and they are less likely to use life skills materials in language arts and social studies classes (Wagner, et al., 2003). 
The extent of time students with disabilities spend in general education settings demands that all teachers - not only special education teachers- - have a role in supporting transition to adult life. If professionals were legally mandated to ensure that students have identified postschool placements, as suggested by Hughes and Carter (2011), would educators use EBPs to increase the likelihood that high school youth with disabilities find success in postsecondary settings? Perhaps, professionals are unaware of transition-related EBPs and how to implement them to maximize transition-aged youth with disabilities' success in postsecondary settings. Evidence-based practices are backed by high-quality research to support their effectiveness and should be implemented across educational settings.

\section{Barriers to Effective Implementation of Transition Practices}

There are multiple factors that interfere with professionals implementing EBPs with fidelity. The professional's unique roles and responsibilities can present differing challenges to implementing EBPs effectively. Teachers' lack of quality implementation of transition services can be attributed to these reasons: a) lack of college preparation, b) a lack of training, or c) a lack of communication regarding EBPs between stakeholders.

Lack of preparation. According to Benitez, et al. (2009), special educators rated themselves from somewhat unprepared to somewhat prepared to deliver transition instruction. On average, Benitez, et al.'s respondents reported that they took one course during undergraduate or graduate school. Approximately half of participants had taken no transition courses, and about half had one to four classes related to transition at the undergraduate or graduate level. Special educators were not alone feeling underprepared to serve transition-aged youth. Overall, rehabilitation counselors rated their preparedness as 2.77 on a four-point scale (Plotner, et al., 2012). Plotner, et al. learned that transition vocation rehabilitation counselors 
either seldom or very seldom attended training during their pre-service preparation. Li, et al. (2009) found a significant difference between the amount of time special education teachers implemented transition practices in relation to the amount of pre-service training they received. Even when provided with training, pre-service teachers were not able to implement the EBPs with fidelity within a classroom setting (Test, et al., 2015).

Lack of training. Mazzotti and Plotner (2016) found over half of transition service providers were seldom or never provided with professional development opportunities focused on transition EBPs. They also found $45.3 \%$ of participants were seldom or never given secondary transition EBP resources. Plotner, et al. (2016) also found that the majority of transition professionals receive limited transition EBP training. Almost half of special educators and almost one-third of direct-service transition professionals received one day or less of transition EBP training per year. Even when provided with training, special educators feel somewhat unprepared or highly unprepared to deliver transition services effectively (Blanchett, 2001).

Lack of communication. Poor communication among all stakeholders also contributes to the quality of implementation of transition services (Plotner, et al., 2012). Plotner et al. explained that "A disconnect has created a breakdown in communication and team work negating an effective collaborative approach to transition services" (Plotner, et al., 2012, p. 141). Test, et al. (2015) explained that students who do not have interagency collaboration on their transition teams experience less successful postsecondary employment and education outcomes. They explained that the more supports available to the student and the more familial input and advocacy that occurs, the more likely the student will find postsecondary success. 
School- and district-created barriers. Educators have identified issues with their school or district's structure and expectations for providing transition services. Mazzotti and Plotner (2016) explained that teachers felt frustrated with school districts because specific EBPs were not implemented over extended periods of time. They further identified that educators and other transition-specific personal (46.0\%) were rarely or never provided with EBP resources. Blanchett (2001) also found that educators were frustrated because many in-service trainings were optional, so there was not consistent training for all educators. Furthermore, Blanchett explained that in-service professional development oftentimes occurred after instruction began, as opposed to before instruction began.

\section{A Case for General Education's Involvement in Transition}

The No Child Left Behind Act (NCLB, 2001) was developed to ensure that all students receive high quality instruction. NCLB (2001) created accountability measures that became known as Annual Yearly Progress (AYP). Schools have been held accountable for achieving AYP in both math and reading/language arts for all students. In order to facilitate progress toward meeting NCLB's AYP goal of all students having grade-level skills in math and reading/language arts by 2014, the concept of co-teaching received increased attention (Cantu, 2015). Due to the increased use of co-teaching, youth with disabilities have received instruction from general education teachers, as opposed to students being pulled out of the classroom to receive separate small group instruction from a special education teacher (Cantu, 2015).

\section{Importance of Collaboration}

Cantu (2015) further explained that collaboration is the key to supporting youth with disabilities in inclusive settings. Collaboration is another responsibility that general educators have for supporting youth (Farnsworth, 2006; Leader-Janssen, Swain, Delkamiller, \& Ritzman, 
2012). Leader-Janssen, et al. (2012) defined specific collaborative roles of general education teachers with different professionals, including special education teachers, paraprofessionals, speech-language pathologists, psychologists, and administration in order to support youth. According to Leader-Janssen et al., general educators are responsible for collaborating with special educators to implement IEP accommodations and incorporate strategies into the classroom setting.

\section{Educational Settings for Youth with Disabilities}

Students' IEP teams must include a special educator, no less than one general educator, the parent of the student, a representative of the school's administration, and any related service providers (IDEA, 2004). Students with disabilities are taught in general education settings for a significant part of their school day. According to the NLTS2, youth with disabilities took a majority of math (52.7\%), science, (66.1\%), social studies (63.9\%), foreign language (85.1\%), any vocational education $(70.6 \%)$, occupationally specific vocational education $(73.4 \%)$, prevocational education (53.1\%), nonacademic (74.9\%), fine arts (87.0\%), and physical education (87.9\%) courses in general education settings (Wagner, et al., 2003). Fewer course options were more likely instructed for youth with disabilities in special education settings: language arts (54.4\%), life skills/social skills (60.6\%), and study skills courses (79.1\%).

A majority of youth with disabilities (60.4\%) take classes in both special and general education settings, and $27.2 \%$ of youth with disabilities take courses completely in general education settings (Wagner, et al., 2003). Nine percent of youth with disabilities take classes only in special education classes. The authors explained that there was a nine percent increase in the amount of time youth with disabilities spend in academic general education settings from the NLTS to the NLTS2. Also, there was a $21.0 \%$ decline for students with disabilities taking any 
classes in special education settings. However, Wagner et al. (2003) also noted that nonacademic courses excluding vocational courses were $27.0 \%$ more likely to be instructed in special education settings.

A student's grade level also correlates to the number of courses he or she takes within general education settings (Wagner, et al., 2003). For example, Wagner et al. (2003) explained that youth with disabilities were less likely to be involved in general education classes later in high school than they were in eighth or ninth grade. Juniors and seniors are $11.0 \%$ more likely to be involved in taking a course that occurs other than in general or special education settings. However, Wagner et al. (2003) noted that these courses only make up a small percentage of the overall courses taken at any grade level.

According to the NCES, $61.2 \%$ of all youth with disabilities spend $80.0 \%$ or more of their day in general education settings. Based on the NLTS2 and NCES data, general education teachers are responsible for teaching youth with disabilities in settings that include both academic and functional curriculum classes within general education settings. Bakken (2015) explained since "the classroom teacher knows the curriculum and ways to help a student access it, the teacher should participate in developing the IEP (p. 8)." Therefore, general educators play critical roles in participating in the development of youth's IEPs and preparing them for adult life.

\section{Gap in Research and Research Question}

Many scholars have argued that EBPs must be implemented to increase successful postschool outcome success. In order to increase the implementation of EBPs, the education system must first go under specific reforms (Lehmann, Cobb, \& Tochterman, 2001; Morningstar, et al., 2012; Test, et al., 2015; Thomas \& Dykes, 2011) According to Test et al. (2015), the need 
for all students to be college and career ready aligns well with the transition planning process. They argue that high school reform would benefit all students if a school-wide transition planning process for all youth is implemented, and Hughes and Carter (2011) also support such a reform. Thomas and Dykes (2011) believe that utilizing the response to intervention (RtI) model to enhance the learning for all students will positively affect postschool outcomes.

As Kohler (1993) wrote 23 years ago, "Current educational initiatives and reform efforts in both 'regular' and 'special' education require that we restructure the organization and delivery of educational programs" (p. 117). This conversation is still occurring today, as Test, et al. wrote "[IDEA] (2004) includes language that requires general educators to provide research-based interventions" (2015, p. 255). Researchers have shown the impact of transition EBPs on postsecondary outcomes for youth with disabilities. Before and after the 2004 amendments to IDEA, research has been published about how equipped transition professionals and secondary special educators feel they are to deliver quality transition instruction (Benitez, et al., 2009; Blanchett, 2001; Mazzotti \& Plotner, 2016; Plotner, et al., 2016). Literature is lacking, however, on how general education teachers perceive their roles in providing transition services and instruction. Such research is critical however, if we are to succeed in school reform that promotes transition-focused education. Therefore, the following research question will be addressed:

1. How do secondary education teachers describe their work related to supporting outcomes for youth with and without disabilities? 


\section{CHAPTER III: METHODOLOGY}

In this qualitative study, I examined general education teachers' perceptions about their roles in supporting all youth's transition to adult life, including what they believed their role was when delivering transition services to all students, including students with disabilities. To determine general education teachers' perceptions of their role, I conducted semi-structured interviews. This study was designed in accordance with guidelines for grounded theory, as originally designed by Glaser and Strauss (1967).

\section{Participants}

My participants were from the central area of a Midwest state. They were secondary education teachers who taught general education classes, either academic or functional, to students with and without disabilities. For this study, general education included: a) core academics, b) vocational education, and c) general education electives.

Initially, I invited general education teachers who worked at 23 different high schools to participate in my study. Three general education teachers expressed an interest in participating. Two of the three respondents agreed to participate. After sending a second e-mail to principals, four more teachers asked for additional information about the study, and two teachers agreed to participate. At this time, my thesis chair completed an amendment to my Institutional Review Board's (IRB) process to include schools within 45 miles of my town. I sent my recruitment email to 26 additional principals. I received requests for additional information from two teachers who later agreed to participate in the study. These general education teachers were my six participants. I included participants from multiple schools to "allow results to be applied by readers to a greater range of other situations," or so my results will be more easily generalized (Merriam, 2001, p. 212). I interviewed six participants. Educators for this study worked within 
60 miles of my town to allow for access. Therefore, the participants were selected through convenience sampling. To recruit, I did the following:

1) Developed a list of high schools within 30 miles of my town.

2) Identified principals at each high school.

3) E-mailed a request for assistance and recruitment flier to principals; principals were asked to forward the recruitment flier to all of the general education teachers in their school. The recruitment fliers requested that interested general education teachers contact me through e-mail.

4) Received an e-mail from three interested general education teachers.

5) Sent interested teachers the Informed Consent document.

6) Scheduled and confirmed two interviews.

7) Sent a follow-up e-mail one week after my initial e-mail.

8) Received an e-mail from four interested general education teachers.

9) Sent interested teachers the Informed Consent document.

10) Scheduled and confirmed two interviews

11) Amended the IRB to include schools within 45 miles from me.

12) Developed a list of high schools between 30 to 45 miles of my town.

13) Identified principals at each high school.

14) E-mailed a request for assistance and recruitment flier to principals; principals were asked to forward the recruitment flier to all of the general education teachers in their school. The recruitment fliers requested that interested general education teachers contact me through e-mail.

15) Received an e-mail from two interested general education teachers. 
16) Sent interested teachers the Informed Consent document.

17) Scheduled and confirmed two interviews.

\section{Professional Background}

Kara. Kara is certified to teach biology with her degree in science education. Currently, Kara teaches ninth grade honors biology and two standard biology courses. She co-teaches her standard biology courses. Kara has been teaching for 34 years; however, this is only her $14^{\text {th }}$ year as a high school teacher. She currently teaches in an urban area.

Jim. Jim has a master's degree in teaching and leadership, and he is certified to teach art in grades Kindergarten through twelfth. Jim has been teaching art for 18 years. He teaches students across grades at the secondary level. His courses include drawing and painting courses, a commercial art course, and a crafts course. He currently teaches in an urban area.

Erich. Erich earned his bachelor's degree in Spanish and later earned his teaching certification. He currently teaches in a rural area and teaches first through fourth year Spanish classes. He is currently teaching his tenth year of high school.

Erin. Erin has her bachelor's degree in communication education and is certified to teach English. She teaches freshman through seniors. Erin teaches sophomore English, Speech I, Speech II, and drama. Erin co-teaches one of her speech classes. She teaches in a rural area, and she is in her fourth year of teaching.

Ron. Ron's initial degree was in music technology. He has since earned his bachelor's of geography education with a minor in sociology. Ron teaches sociology and U.S. History in an urban setting. He is currently earning his master's degree in history. Ron is teaching his fifth year of high school. 
Michelle. Michelle received her degree in special education and taught for six years in a late elementary setting. She moved to a different position where she co-taught as a special educator in a high school setting. She received her master's in special education. In 2006, she earned her English endorsement and began her career as a general educator in 2007. Michelle teaches Senior Skills, and she co-teaches English I in an urban setting. Overall, she has taught for 27 years.

Refer to the Table 1 for a summary of participant information. 
Table 1

Participant Information

\begin{tabular}{|c|c|c|c|c|c|c|}
\hline Name & Age & $\begin{array}{l}\text { Years } \\
\text { Taught }\end{array}$ & Degree & Content & Co-Teach & $\begin{array}{l}\text { School } \\
\text { Setting }\end{array}$ \\
\hline Kara & 56 & 34 & $\begin{array}{l}\text { Bachelor's of } \\
\text { Science } \\
\text { Education }\end{array}$ & Biology & Yes & Urban \\
\hline Jim & 41 & 18 & $\begin{array}{l}\text { Masters in } \\
\text { Teaching and } \\
\text { Leadership (K-12 } \\
\text { Art endorsement) }\end{array}$ & Art & No & Urban \\
\hline Erich & 32 & 10 & $\begin{array}{l}\text { Bachelor's in } \\
\text { Spanish and later } \\
\text { earned teaching } \\
\text { certificate }\end{array}$ & Spanish & No & Rural \\
\hline Erin & 26 & 4 & $\begin{array}{l}\text { Communications } \\
\text { Education with } \\
\text { English } \\
\text { endorsement }\end{array}$ & $\begin{array}{l}\text { English and } \\
\text { speech }\end{array}$ & Yes & Rural \\
\hline Ron & 34 & 5 & $\begin{array}{l}\text { Bachelor's of } \\
\text { Geography } \\
\text { Education with a } \\
\text { minor in } \\
\text { Sociology; } \\
\text { Currently } \\
\text { studying master's } \\
\text { degree in history }\end{array}$ & $\begin{array}{l}\text { U. S. } \\
\text { History and } \\
\text { Sociology }\end{array}$ & No & Urban \\
\hline Michelle & 49 & 27 & $\begin{array}{l}\text { Master's in } \\
\text { Special } \\
\text { Education with } \\
\text { English } \\
\text { Endorsement and } \\
\text { Certification }\end{array}$ & English & Yes & Urban \\
\hline
\end{tabular}




\section{Instrumentation}

I developed interview questions for this study. The interview questions were developed through reviewing the scholarly literature on transition practices for youth with disabilities and postschool outcomes. Pairing the National Technical Assistance Center on Transition's

(NTACT) (2016) current best practices for postsecondary success for transition-aged youth with disabilities with current and historically significant research on transition practices (Benitez, et al., 2009; Kohler, 1993; Mazzotti \& Plotner, 2016; Mustian, et al., 2012; Powers, et al., 2005; Test, et al., 2015), I developed interview questions to accurately assess general educators' perceptions of their role in the transition process.

I piloted the interview with three general education teachers. I requested their feedback about the wording of the questions and structure of the interview, as well as responses to the interview questions. Based upon the answers and feedback provided by the pilot group, I refined the questions to ensure clarity and accuracy of interview questions. My thesis committee and I made final changes to the interview protocol prior to its implementation. The appendix contains the semi-structured interview protocol that was used for this study.

\section{Procedures}

I sent a recruitment e-mail to the principals of each identified high school. I asked the administrators to forward the following information to general educators who teach students with and without disabilities. For this study, general education teachers included individuals who taught the following general education curriculum: a) core academics, b) vocational education, or c) general education electives. The email included a letter requesting participation. In the letter, I explained that the purpose of the study was to learn about general education teachers' perceptions related to transition planning for adult life. Once potential participants returned an 
email expressing interest, I sent them the informed consent form. The participants were required to provide consent for participation. I requested interested participants contact me to schedule a time to meet. A week later, I sent a follow-up e-mail to gain additional participants and confirm interview dates and times.

\section{Interview Process}

I visited the participants at a location and time of their preference that worked with my teaching schedule. I arrived at the interview location approximately ten minutes before the scheduled interview time to meet the general education teacher. Then, I used an iPad to record audio data from the interview. Additionally, I collected field notes in my interview notebook. I collected data on participant's body language, tone, reactions to the interview protocol, quotes, comments, and environmental factors. After the interview, I thanked each of the participants for their time.

Interviews were between 21 minutes and 47 seconds and 70 minutes and 12 seconds. Transcripts ranged from 9 pages to 20 pages with a total of 100 pages. A semi-structured interview allowed for enough flexibility to collect the in-depth data necessary for this study. The protocol also allowed for me to have a list of open-ended questions. Lastly with a semistructured interview, I asked my participants clarifying and follow-up questions.

\section{Security Procedures}

All data were recorded with a password-protected iPad. The iPad may only be accessed using a fingerprint or access code. Since I am the only person with access to the iPad, the risk of the respondents' information being exposed is minimal. When the iPad and notebook were not with me at the interviews or being used to transcribe or code data, they remained in a locked filing cabinet. The physical copies of the data were transferred to my laptop. The computer is 
password-protected, and I am the only person with its password. All participant names' were replaced with pseudonyms. I stored the list of names and their matching pseudonyms printed on paper in the locked file cabinet in my thesis chair's office.

\section{Data Analysis}

I reported results from my findings in a written report. Pseudonyms were used for the participants to protect confidentiality. All recorded interviews were transcribed verbatim. I used the constant comparative method to analyze my data as designed by Glaser and Strauss (1967) as a part of their grounded theory. Merriam (2001) explained that I constantly compared my data beginning with my interviews and field notes until "a theory can be formed" (p. 159).

Prior to coding, I was looking to find transition planning terms. Based on the transition literature reviewed, I pre-determined to look for terms including self-determination and its various components. I looked specifically for these terms because the literature emphasizes its importance for adult life.

To analyze my data, I first transcribed my data. Once all interviews were transcribed, I read through each interview to look for main words and ideas. Next, I identified these words and themes as codes. Afterwards, I found similarities among the coded words. From the coded words, I looked for repeated words and words with similar meanings. Next, I put the coded words into categories and subcategories.

Next, I used axial coding to analyze my data. With the help of an independent researcher with a doctorate in special education and experience with qualitative analysis, I analyzed how the coded data interrelated and how data affected or related to one another. Based on their perceptions, I examined how these general educators were involved in the transition process. I analyzed situations that may influence their use of transition practices and any results of the 
educators' implementation of transition services. I drew a coding paradigm to organize themes and categories visually. This helped me to see if there are relationships between the categories and themes. Next, I selectively coded my data. To do this, I further examined the relationships that I find from my coding paradigm to write a narrative about how my data were connected.

To triangulate data, I combined data from multiple sources. I will have multiple participants' responses to interview questions. By having multiple data sources from interviews, any themes or patterns which emerge from their responses will be more valid and reliable. Also, I have my field notes collected from the participants' interviews. Including information from multiple sources will help me report my findings in a more thorough and accurate fashion (Creswell, 2002).

As suggested by Brantlinger et al. (2005) and Merriam (2001) as a credibility measure, five of my six participants reviewed a summarization of my results and confirmed that they believe my results accurately depicted their perceptions. One participant stated that he saw himself presented in certain themes more specifically than others, but overall he felt he was represented within my themes. Additionally, I requested interviewees confirm direct quotes that I included in my results section. Five participants confirmed their quotes and permitted me to use them. One participant requested that I not use certain quotes because she was concerned that her quotes may identify the people about whom she spoke. Therefore, she granted me permission to modify some of her quotes to speak generally about the situation. Also as suggested by Brantlinger et al. (2005), this study was designed through a collaborative fashion between my thesis chair, committee members, and myself. 


\section{CHAPTER IV: ANALYSIS OF THE DATA}

\section{Results}

Respondents have self-identified how they prepare all students, including students with disabilities, to transition to life after high school. Broad themes identified from participants include the following: a) having desired student outcomes, b) exposing students to postsecondary options and helping them set goals, c) facilitating opportunities for students to develop needed skills for adult life, d) general education teachers' participation in IEP meetings, and e) communicating and collaborating.

\section{Desired Outcomes}

Based on identified themes, the participants have three desired outcomes for their students: a) be critical consumers of information, b) use accurate information, and c) develop empathy. Through the use of their content, the respondents facilitate opportunities for students to achieve these outcomes.

Critical consumers of information. Kara, Erin, Ron, and Michelle all want their students to become critical consumers of information. Kara teaches her students to use the scientific method. She explained that with the scientific method, students should be able to replicate someone's results. Kara teaches students to question what they see. When showing her students a famous cleaning product's commercial, she asked her students the following: "Does this make sense? What's happening here? Do you believe his claim?" She asks her students these questions so they become critical consumers of information. Kara taught her students about "observation, drawing conclusions. Are your conclusions accurate, or are you inferring them based on what you've seen that may not even be accurate at all?" 
Erin explained that she wants her students to "make their own conscious decisions about things instead of just following the news." Erin hopes when her students become adults that they will think "I am buying this product because it's a quality product, not necessarily because someone said something that I liked or I liked the person." Ron also values the importance of adults using information critically. He hopes his students will "think more critically about power and their role in it and will help them function as a human being in our society and make it better." Erin hopes that when her students become adults, they will not be "sheeple." She explained "sheeple" were the people who followed Julius Caesar without questioning. Erin shared that her students "didn't want to be the 'sheeple." After explaining to her students about "sheeple," Erin hopes that her students will think critically.

Instead of researching and making their own informed decisions, Michelle explained that young people tend to agree with their families on political views. She further explained that as adults, her students will be "privy to a lot more information, and the only thing I'm going to tell you is there's so much bias. It is impossible - nearly impossible — to find something that is not biased." By being aware of biased information, Michelle hopes her students will make informed decisions for themselves.

Use of accurate information. In order to be a critical consumer of information, Kara, Erin, and Michelle discussed the importance of using accurate information. Kara thinks using accurate information comes down to thinking about what you see. She elaborated that "I want them to think — just think." She explains that sometimes "we get too caught up with terminology." She wants her students to "just think" about the information that they see or hear.

Erin teaches her students how to research. She wants her students to begin "understanding this is a credible source versus this is not a credible source." Michelle is also an 
English teacher, and she also teaches about using credible sources. Michelle explained that you can write a blog about a topic without being an expert. She encouraged her students to "think about your sources." She explained the following:

You can't get your information from somebody's blog. I can write a blog about Donald Trump, and I haven't read, you know, very much. I'm just going by what I see on whatever news source I watch, and I write that blog. That does not make me an expert. You've got to be careful where you get your information. I think that might be the lifelong thing they can take from it: is think about your sources.

As Kara stated, Michelle would also like her students to "think" about the sources they are using.

Empathy. Along with being critical consumers who make decisions based on accurate information, these general education teachers would like their students to develop empathy. Erich, Erin, and Ron all discussed the importance of empathy.

Because Erich teaches in a rural school, he hopes that his students will develop diversity awareness. He also wants his to students have "cultural knowledge." Erich hopes students will carry their awareness and knowledge and carry it into postsecondary settings: "rather than think 'Oh, that's different. That's wrong.' They might have a little more empathy and be able to see it from their point-of-view rather than be steadfast in their own view." Like Erich, Erin also teaches in a rural community. She hopes that her students will develop an "awareness of where other people are coming from." She hopes that students will try "getting rid of that ethnocentric view of life...to see other viewpoints." By helping students develop diversity awareness, these participants hope that they will become more empathetic in their daily lives.

In his courses, Ron uses current events to help students develop empathy. In his classes, he explained that they discuss transgender issues. He is hoping for students to try and empathize 
with their peers. He explained that his students are "just really open to it because most of them don't know anything about it." Ron further explained this about his students:

And then the students that we have in the building who are struggling with it, they're like 'Oh!' I mean the other students finally, some of them get it... 'Like, now I understand why this person is like late to PE every day because they have to walk across the entire building to go to the one bathroom in the building where they can change comfortably.' Although Kara did not specifically discuss empathy, she did discuss respectful behavior and treating people respectfully. Kara explained that she wants her students to know "how to be a good person." Former students tell Kara what they enjoyed about her class. Although she appreciates and values their feedback, she stated that she would like to know "that they've treated people the same" way in which she treated them. Kara encouraged her students to further be respectful to others with this example:

What do you do when you see somebody in the atrium out here, and I said "Never do you see him eating lunch." What would be wrong with you saying "Hey! We've got room at our table. Would you like to sit with us?" I said "You can do that all the time." I said "Do you know how thankful somebody would be if you said that? Do you know how thankful somebody would be if you said 'Do you want to study for this test?'”

Jim also did not specifically discuss empathy, but he discussed the importance of working together with each other. He wants his students to understand that "We're all in this together." Helping his students work together is how Jim helps his students work with others, even if they have differing views or beliefs.

Michelle wants her students to be willing to listen to other people. She does not value fighting or name calling. She tries to instill the following into her students: "Just because 
somebody doesn't agree with you or isn't 100 percent like you, doesn't mean you can't

understand or show compassion.” These participants explained the importance of understanding others in order to develop empathy.

\section{Postsecondary Exploration}

When asked how they helped prepare students for life after high school, all six participants identified different ways in which they helped students explore their postsecondary options. Participants helped with goal setting, provided in-class exploration opportunities, and gave general guidance.

Goal setting. The general education teacher participants in this study helped students set goals for life after high school. In order to help students set goals, the students needed to know their available postsecondary options. Some of the respondents discussed helping all students and then specifically helping students with disabilities to set achievable goals based upon the students' strengths, interests, and preferences.

All students. Michelle presents postsecondary exploration opportunities to her classes. She discussed the importance of knowing your options: “It's okay if you don't have it figured out yet, but I want you to know your different options that are available." She brings in guest speakers to discuss different postsecondary options the students have: a) the military, b) a local technical college, and c) a local community college. She is also searching for guest speakers to discuss the trades as postsecondary options in order to provide her students as many options as possible.

As Michelle helps introduce her students to various postsecondary opportunities, she explains to students that "I'm your life guide on this journey, but you have to go on your own at some point. It's no good living my life. I've been there, done that. You live your own journey." 
To ensure that her students are prepared for entering postsecondary life, Michelle presented her students with multiple opportunities to explore postsecondary opportunities.

Jim also mentors students about postsecondary options available to them. In his classroom, he has a bulletin board on which he displays opportunities for secondary and postsecondary students. "I also try to keep a board. It's kind of like things you get from colleges and other artists...to share with the kids, so that they can think about the future." He uses this information to mentor students about options that are currently available to them. Jim also encourages his students to explore their options.

Michelle also encourages her students to invest in their futures. She explained that many of her students may have difficulty paying for college. In order to reassure them that money should not stop them from setting their desired goals, she shared her personal story about how she made it through college:

I worked five jobs, and I worked in the summer. I was one of seven kids, and I got scholarships and grants... [Unfortunately], I couldn't get the Pell grant anymore. So, you know, I had to apply for different scholarships. I had to work at a summer at a glass factory. I had to do things I didn't like, but I made it through with no loans... But I'm like "Here's the deal, though. Don't let loans deter you from going to college. So what? It's an investment in yourself, and every month you pay that back after graduation, you've invested in you."

Michelle also understands that a four-year degree is not for everyone. She explained that her husband has "his associate's...I have my master's plus 48, and he makes more than I do. He's only been there 15 years, and I've been teaching 27." She wants her students to be aware 
that postsecondary options are available in which students can be financially successful and not need a four-year degree.

Kara presented a unique viewpoint from other participants on her role with preparing all students for life after high school: "Sometimes to prepare students for life after high school, you gotta get them through high school." She focused on the immediate goal of passing high school to help students prepare for adult life.

Students with disabilities. Michelle encouraged families to realize that students should follow their own dreams. To outline how she helps students set their own goals and follow their dreams, she outlined how she had a student with a disability whose freshman year goals were heavily influenced by his family. Each year, his goals changed. His postsecondary goals started with attending a four-year college, then community college, and his goals kept changing. She explained that the parents "little by little, they started to see that their dream wasn't [the student's] dream." The student wanted to have his own business, and his family provided support to begin his business. Michelle explained the following: "[The student's] going to be just fine, but it was like just because that was your path, it's not your kid's path. So, I guess that's the one thing is follow your own path." Michelle helped her student find his own meaningful postsecondary goals. Additionally, she also helped the student's family understand that the student could still be successful if he took a different path than they did.

In this example, Michelle questioned if the goal was realistic for the student. As Michelle outlined this situation, she wanted to ensure the student's goal was attainable:

Here's the deal. I hear what you're saying, mom, but what does he want to do? She said "He wants to go to Harvard or Yale and be a neurosurgeon." ... So, I said "Okay if that's truly what his track is, we have to really look at what these accommodations are because 
we are doing him a disservice because he is not going to be prepared for Harvard or Yale when he goes in four years because Harvard or Yale are not going to offer reduced items on tests or limited multiple choice options."

Sometimes, students may have difficulty stating their wants and goals to their families. Therefore, Michelle will help her students communicate their future goals with their families. She explained that "I have to be the voice for the kid when that's not what they want to be. I have to try to help them have that conversation because mom or dad is like 'You're going to a four-year school."' Michelle helps advocate with her students, so the student's goals are shared with their families. Because of Michelle's help, her students' feedback is heard and valued.

Postsecondary goals may change. Both Ron and Michelle explained that it is acceptable for students to change their postsecondary goals. Michelle shared personal stories during this interview and with her students about how her husband and other family members have changed their postsecondary plans. One example was about her nephew:

My nephew was 26 working at [a large company in the South], and they were trying to move him to management track. He said "I don't want to do this," and he went to school and became a pharmacist. And he has up the wazoo loans, but guess what. He's a pharmacist, and he'll have a career for life.

Ron shared personal stories about how he decided to change his postsecondary plans. He detailed his journey becoming a teacher: "My first degree is in music: electronic music, computer music... Drop out and start a band or like I should have done that first before I went to school. I didn’t. I did that after. Before my second degree, I did the band thing." He shares how he changed his postsecondary plans with his students, so they understand that it is acceptable to change their plans. Without exploring postsecondary options, it could be difficult for students to 
plan for adult life. Therefore, Michelle and Ron provide their students with opportunities to learn about postsecondary options. They also reassure their students that it is acceptable for your goals to change.

In Ron's class, he presents a project that helps students explore self-identified interests. He detailed the project and its expectations: "We start this 20 percent project where they are free to do anything they want that they're passionate about, as long as they do it in a way that offers some sort of social good." To name a few examples, he has had students organize fundraisers, learn sign language and teach sign to others, and also start a community resource garden. When asked the purpose of this project, he explained the following:

Don't go major in accounting because it's safe when you really love painting...It's like go paint because you're going to be good at that because you love it...That's what I want them to do, and that's when you're going to be the most successful and do the most good. So, I think giving them the opportunity to do something that they don't otherwise get to do in this environment might allow some of them to see that.

College is not for everyone. Michelle's postsecondary exploration goes beyond just exposing students to options available after high school. She explained "I try to be a realist." Michelle told her class the following: "College is not for everybody. Some of you who sucked at high school will really enjoy college. Go take one class next year or two... Just take a couple of hours, get a feel. See if you like it." Michelle mentors her students and understands that not every student will or should go to college. Michelle was not the only person who discussed that college is not for everyone. Ron explained that students should be asked "What do you love?" instead of being asked "How are you going to make a living?" He further explained that "If you don't know what you love, then explore. Take some time. Don't just go to college and get like 
80 grand in debt to do some bullshit that you hate." Michelle told her students "Follow your own path." Ron discussed with his students the importance of exploring options prior to entering college because that is what students feel the expectation is. He explained that he told his students to explore options and travel because after exploration, "you might actually know what you want to do and not waste your time.”

General guidance. Multiple participants discussed general postsecondary guidance they provide. This guidance was discussed and shared by participants through their own personal stories, by providing career guidance, and by encouraging students to follow their dreams.

Personal experiences/stories. Half of the respondents, Kara, Ron, and Michelle, explained how they shared their personal experiences and stories with students. Although the topic of the personal story may change by person and situation, the overarching purpose of helping students remains.

By sharing her personal experiences, Kara helps her students learn social expectations. One example she shared was "about a time in my life where I called a teacher out, and I thought I was being helpful. And the truth was the teacher got very angry at me, and I had never been told this is not the way you handle this." She teaches students these social expectations directly, so they can carry themselves in a socially appropriate fashion. Furthermore, Kara wants students to learn from her mistakes, so they are prepared for postsecondary social expectations.

Ron also uses his personal experiences to teach his students. He has a different focus than Kara. Ron explained that he became a teacher, but he did not take the traditional route. He shares with his students about his first degree, which was in music. He explained that his mom did not ask about the practicality of the degree. Instead, she asked him "Do you love making weird electronic music?" He said "Yes I do." To which, his mom replied "Then, you should do 
that." He explains his students should do what they love because that's when they will be the most successful.

Of all the participants, Michelle shared the most personal stories and experiences about her and her family. Michelle's stories all related to what happened after she exited high school. Michelle discussed some of her personal obstacles that she had to overcome. She explained that “I talk to my students all the time like I know some of you don't have a lot. I didn't have a lot either. I made it through, though." She wants her students to know that with perseverance, they can be successful. She also told her students the about how she has had difficult conversations with her own family members about college: "If you don't want to go, don't waste your time and my money." Her realistic approach to postsecondary goals benefits both her students and family.

Five of the six participants explained how they provided individual supports specifically focusing on transition. Other than IEP involvement, participants provided additional transitionrelated supports, including sharing information about attending college, giving career guidance, and encouraging students to follow their dreams.

Attending college. All six participants discussed specific skills needed to attend college, and four of the participants shared specific information and supports for attending college with their students. Erich explained that he provides informal guidance. He explained that "I'll just in passing ask them 'Hey! What are you looking at? What do you want to study?'” He offers some "gentle guidance in the right direction." If he is not sure how to support the student, Erich refers him or her to the guidance department. Along with providing social validation, Jim also helps students and their families learn about the specific differences between college programs. He wants to be sure that they can make the best decision for them. Erin shared her experiences with attending college, as does Michelle. 
Career guidance. Ron and Jim both provide career guidance to students. Jim involves parents with career guidance. He offers informal suggestions and guidance. Jim tells students "This is something you might have a future in, and if you're interested in this, just let me know." Jim will also call home and say "You know, Johnny's really good at doing this stuff, and this is something he might want to look into in the future.” Ron also shares postsecondary options with his students, including careers. He tells students that "I just want you to know what you're doing."

Follow your dreams. Ron and Michelle encourage their students to follow their dreams. Michelle told her students "Follow your own path." Ron encouraged his students to follow their dreams as well. Both explained that you can be successful without going to college. Ron discussed with his students the importance of exploring your options prior to going to college. He explained that he told his students to explore options and travel because after exploration, "you might actually know what you want to do and not waste your time."

To help students follow their dreams, Erin and Ron were asked to write letters of recommendation for their students. Erin shared her experiences with writing letters of recommendations: "I have helped two students get into a study abroad program... I have a student in Spain right now." Although no other participant had mentioned helping students enroll in a study abroad program, Ron has also written recommendations. Ron explained "kids come into your office and talk to you about stuff and letters of recommendation...we're always all writing letters of recommendation like all the time for like two months at that time of year."

\section{Developing Skills}

All participants described how they help students develop needed skills for adult life. Participants described four areas relating to skill development: a) understanding their respective 
content's role in transition, b) describing general practices, c) integrating interpersonal skill instruction, and d) incorporating self-determination instruction.

Content's role in transition. When asked how their content relates to adult life, all six participants articulated a connection to life. For Erin and Michelle, they explained how their content relates to life after high school. Some of the examples they discussed, included using factual evidence, speaking skills, and research skills.

Kara explained that her content relates to life after high school because of the functional skills she teaches. She explained "Nothing we teach is sacred...There are many good people out there who have never taken a course in biology." Therefore, she tries to figure out "the need of the students that have my information. How is it going to help them down the road?" She wants her students to have meaningful instruction for them. For example, Kara helps her students with study skills. To help students feel like they can succeed, she believes "the biggest thing I think is turning kids around on their study skills... And a lot of times it's just they don't write anything down. Their notebooks are disorganized, and we straighten out as much of that as we can."

Jim, Erich, and Ron all teach elective courses. Erich discussed how his content helps students learn a new language and also helps them, in theory, develop their English skills. Jim stated that most people will not be artists. Along with the content-specific art skills, he focuses on the functional skills that students will need as adults. For students to prepare for adult life, Ron wants students to know that it is acceptable to ask questions. He hopes his students will question the status quo.

Real world examples. Each participant related his or her content to real world examples. Kara asked her students “How do you know if this person's choking? We talked about could they speak...a lot of it is social. Some of it is practical." She taught real world examples of her 
content. She discussed heart disease, people choking, and scoliosis. After discussing functional and relatable real world examples, she then explains "the biology of it."

Jim places a large emphasis on collaborative work within his classroom. He wants his students to know that "when they get out into the real world, they work with the people that are different than them or the same as them and...reach a common goal and be able to take criticism, and become productive members of society." When Erich teaches about culture, he explained that it "gives them more of a world view that they can take into account that things aren't like they are here everywhere."

In her class, Erin relates current events to her nonfiction unit of instruction. Some of her current even topics were the presidential debates, Malala Yousafzai, and the burkini. She explained that the students enjoyed learning about Malala because "they could connect with [her story] because she was so close to their age." In the examples provided by Erin, the events relate to what occurs in the world. Erin wants her students to realize that there is more to life than what they see and experience in their rural community. With the presidential debates, her students will soon be old enough to vote. Therefore, it is imperative they understand how the election process runs for when they are old enough to vote. With current events about Malala and the burkini, Erin hopes to teach her students that they can advocate for change.

Along with discussing history and sociological content relating to life, Ron uses his 20 percent project as a catalyst for relating his content to real life. He wants his students to get involved with creating social good within their communities. Ron explained his rationale as "I just want them to get involved in something. You're more likely to get involved in activism later if you do something when you're younger." 
Michelle also explained how her content relates to life by describing the skills that she teaches and how they relate to adult life. She engages students by asking thought-provoking questions to help improve their critical thinking skills: "Think about it as a lawyer. What support — what quote would you pull out that the nurse said or Juliet said that would prove that the nurse has a responsibility for Juliet and Romeo dying?"

These general education teachers have provided different examples of how their content relates to adult life. By doing so, they are hoping to have students better prepared for adult life.

General practices. Each of the respondents discussed how their general practices relate to supporting youth with and without disabilities, as they prepare to transition into postsecondary settings. Participants discussed accountability, differentiation, and modifications and accommodations.

Accountability. These general education teachers described their accountability practices. Participants discussed accountability for all students and specifically for students with disabilities.

All students. Erin holds students accountable with her absent work policy: "So like my absent work policy: it's their responsibility to come see me about their absent work. That's something I stress very much.” Along with Erin, Michelle holds students accountable with her absent work policy. She will ask students this question: "Did you check Google Classroom...because I put [what we did in class] up there every day...you don't have to necessarily print it out but read what we are doing." Michelle described how she provides resources to her students, so she can hold them accountable for their makeup work. 
Michelle also explained that she holds students accountable for their academic honesty. She wants her students to do their own work: “Don't copy someone else's [work] because I have visual memory that's insane, and I will remember, and I will nail you, and I do."

According to Erin, holding students accountable is important for their adult life. Although these respondents outlined some differences with their accountability measures, Erin defined the importance of accountability for students transitioning into adult life: "You need to be accountable for yourself. People are not going to follow you around your entire life and tell you what to do."

Students with disabilities. Kara quite simply explained that for each student, "there will be accountability." However, she does understand that students with disabilities may need "a different form of accountability... To the class, the students would observe that they're being treated the same." Kara was not alone with explaining that she holds students accountable, but she was the only person who specifically mentioned how accountability may be different for student with disabilities.

High expectations. Findings from the interviews of the six general education teachers also include high expectations for students. Four of the six participants described the importance of having high expectations. Participants discussed high expectations for all students and also for students with disabilities.

All students. Jim discussed the high expectations he has for his students. He explained "Well, expectations is a big thing. I'm also a coach, and I teach and coach pretty much the same. And it's like why bother doing something if it's not worth doing right?" To further explain the need for high expectations, Jim stated "You're not just sitting waiting for things to happen. You're going off trying to make things happen." 
Students with disabilities. Kara described her high expectations for all students, but she specifically stated this about students with disabilities: "I would expect them to achieve at their highest possible level, but sometimes you just have to realize they've got to have some extra interventions." Kara understands that students with disabilities may need additional support, but they can still achieve their goals. Therefore, she maintains high expectations for them.

Like Kara, Ron also discussed his high expectations for students with disabilities. $\mathrm{He}$ explained:

Maybe you're going to take 45 minutes longer than everybody else to read this, but you're still going to read it. I expect you still read it. I expect you to still read it, and you don't have to fully understand it in the end, but we'll talk about it.

When comparing her students with and without disabilities in relation to her class expectations, Michelle explained that "I don't think it really differs that much. I want them to expect the most from themselves as well."

Differentiation. All six participants discussed differentiation of instruction. Kara, Ron, and Michelle discussed how they differentiate their instruction. For Kara, she discussed that she instructs multiple biology courses. "The honors biology classes go in more depth. Their tests are harder. Quizzes are harder. They're expected to work more independently in groups than a standard biology class." She further explained that her honors courses have more essay questions, more difficult multiple choice questions that require more discernment to select the correct answer, and they may have to design their own procedure in a lab activity. This compares to her standard biology courses, which she described in this way: "While we do not try to dumb it down, it is much more straight forward." 
As opposed to discussing how his classes are differentiated, Jim discussed how he differentiates his coursework based on an individual student's ability. He described this example for a student with fine motor difficulties:

Instead of having [the student] try to draw the details and not do it well, what we can do is then have them make things more gestural. And so they're using, instead of small, controlled details, they're using broader, more sweeping kind of movements with their hands, and it allows them to still draw a similar image as everybody else, but they're just kind of approaching it in different form.

Michelle also discussed how she differentiates instruction for her classes. She had this to say about how she differentiates her instruction:

The differentiation is based on availability of materials, reading level of the materials that the kids will have access to through our database through IMC. It's the GALE student resources, and it has reading like reading ability...green is basic...one's intermediate, and one is like super high, so we look at their MAP scores and draw kind of three groups...The top tier who need that extra challenge have definitely more analytical more inferential type questions...Not that we don't make kids who are struggling at the bottom do that, but it's just different plus the material. They might have some background.

Although they have different approaches to differentiation, differentiation was addressed by multiple participants as being important.

Academic supports. All participants described how they provide academic supports for their students. Findings from the participants' descriptions of implementing student supports fell into two categories: a) class-wide supports and b) disability-specific supports. 
Class-wide supports. Ron and Michelle both described how they provide supports for all students, not just for students with disabilities. Ron described how he ensures that he is meeting IEP and 504 requirements by providing supports for all students:

And I do read the IEPs and 504s. If some of them have really severe issues, that's important for me to know, but it usually doesn't impact what I'm doing in the classroom because I'm already trying to do that stuff anyway. I don't think there's ever been a case where I've read an IEP, and I thought "Well, I'm going to have to go out of my way to do that." I don't think that's ever happened. It's like “Oh, yeah. Of course, I'm going to do that." I don't see what the problem is.

Since Ron provides supports to all students who need additional assistance, he is also compliant with his IEP responsibilities. Ron also explained that he does not understand why an IEP is required for teachers to provide additional supports to students:

I offer unconditional support for everything. You know, it's like people who need extra time, they get extra time. It's like 504s and IEPs like I couldn't give a shit less about those things. To me, it's like "Why do we even have to have those? Why is it even necessary? If a student needs extra help, give them extra help. If they need extra time, fucking give them extra time. What the fuck is wrong with you?" If you have a student who is like "I need an extra twenty minutes on my math test." And you're like "no." Like why would you? Why? What's the purpose of that? Do you really need a legal document to force a teacher to give them extra time? It just seems so superfluous and unnecessary and demeaning to everybody involved.

Like Ron, Michelle also offers supports for all her students. She described how her classroom procedures are designed: 
We also allow like on test or quiz days anyone who's an auditory learner can go with [my co-teacher]. So, some kids with IEPs choose to go. Some don't. Some are just gen ed. Some are like the number one kid in the graduating class, but they just like to hear it read out loud.

Both Ron and Michelle explained how they address the needs of students by providing classroom supports to all students, as opposed to just youth with disabilities. Furthermore, Ron explained that he ensures IEP compliance by providing additional supports as a part of his classroom procedures.

Disability-specific supports. Four of the six participants specifically stated that they were following IEPs and implementing accommodations and modifications for their students. Kara provided her rationale for following an IEP: "Modifications are being made, and of course I legally have to follow anything in an IEP...I will follow it because it's a legal document." Erich explained, "I do the accommodations and modifications to help them out." Erin described how her IEPs have modifications listed: "Our IEPs, we have modifications that are checked off, so it kind of has a list of modifications...I'll look at their IEP, and that's checked off." Ron explained his implementation and accommodations in this fashion: "So, I go to the meetings. "Are you doing—are you meeting their accommodations?' 'Yes. Yes I am."”

Interpersonal skills. All six of the participants explained how they teach interpersonal skills. The different skills, included social skills, communication skills, and social appropriateness.

Social skills. Kara, Erin, and Michelle described how they teach social skills. Kara joked "I try to teach social skills...because you can go to Walmart and find out who didn't get the lessons." Kara shared an example when a student had asked Kara if she had her haircut. Kara 
stated that she will say "yes" and wait to see if the student states anything else. If the student does not respond, Kara explains the following: “I don’t know what you're thinking about my hair, but it's good practice that if you notice somebody is wearing a new shirt, if you're going to call attention to it, then you immediately say something positive." Otherwise, she encourages students not to comment about what they notice because their comments "could be misunderstood."

Erin uses her class as an opportunity to teach students about the difference between conflict and argument. She explained that her students begin the year believing that conflict means "arguing and bickering." However as the year progresses, students learn how to work through their conflict and gain a new understanding that conflict does not necessarily mean arguing.

Michelle again shared a personal story to help her students understand how to use social skills. Michelle explained that she disagreed with a person's perspective on social media. She told her students that "I have people I've disagreed with on Facebook-respectfully disagreed with, and that's the difference. Don't start calling people names...I can disagree with somebody and not call them a name."

Communication skills. All six participants discussed teaching communication skills to their students. Erin focuses on teaching her students to "communicate effectively to people." In her direct instruction on communication skills, she includes instruction on both verbal and nonverbal communication. She also directly teaches about making eye contact and showing confidence. Michelle also directly teaches students about speaking in front of others. Kara, Erich, and Ron address communication skills situationally, as students are working in groups or in class discussions. 
Jim was another teacher who addressed communication skills within his class. He had a student who had taken his class twice, but the student wanted to continue working on his art skills and also needed to improve his functional communication skills. While the student was in his art class, Jim facilitated opportunities for the student to work on initiating conversations because the student needed to practice that skill. Jim tailored his course in such a way that the student "was able to initiate conversations. He was able to respond thoughtfully to the questions that were being asked of him." Jim admitted that the student improving his functional communication was more important than the student learning art skills.

Social appropriateness. Kara, Erin, Ron, and Michelle teach students about social appropriateness. Kara teaches students about social appropriateness in multiple ways. For example, she shared that a student made a comment about a different student's speech impediment. She addressed the student and explained that the comments were not acceptable. Kara also has shown her students how her scoliosis affects her. When they responded by saying "Oh!" she explained "You know you don't want to react that way to somebody." Kara teaches socially appropriate communication through teachable moments. Conversely, Erin directly addresses socially acceptable behavior through a project she teaches. Students create a presidential campaign platform. As a part of this project, students were required to think about how they would want their candidate to be represented. Erin explained that the students learned about using social skills. She explained that oftentimes students will begin by stating things they find humorous. However, their socially appropriate comments develop throughout this project because the students want their candidate to win.

Erin also explained that she wants her students to be "socially acceptable... using specific language for specific groups of people and remaining politically correct." Ron echoed this same 
sentiment. He explained that he uses current issues to cause students to think about others' perspectives.

Like Kara, Michelle also uses situational opportunities to teach social appropriateness. Her seniors give a last lecture to her freshmen. She explained that seniors are giving "advice to freshmen." She only has had to ask one student to leave during a last lecture. Her students "get personally offended" when students are not listening to something so personal. She had to explain to the student "If you don't want to hear it, there's the door." She explained why the behavior was unacceptable based on the given situation.

Self-determination. All six participants discussed different components and aspects of self-determination. The components most frequently discussed by participants were selfadvocacy, self-management, self-awareness, and goal-setting.

Self-advocacy. Jim supports his students with self-advocacy. When they need assistance, they must first ask "each other before they ask for my help." He encourages them to advocate with their peers first to address their needs. However if students are unable to answer the questions, they may then ask Jim for support.

Erin and Michelle both have similar homework policies. Erin explained "it's their responsibility to see me about their absent work." Michelle posts her homework online, and she expects that students will advocate for themselves appropriately. She explained students should not ask her "What did I miss yesterday" or "Did we do anything yesterday?" Instead, she prefers that students use the available resources and ask specific questions relating to the missed work.

Ron approached self-advocacy from a broader perspective than Erin, Jim, and Michelle did. He wants his students to learn to "question the rules." He wants his students to ask if something is "the right thing to do." He explained that in life, students should learn to question 
rules or laws with which they do not agree. On the other hand, both Ron and Michelle wish students would quit asking "Can I go to the bathroom?" Ron explained "I make a big deal about them asking me to go to the bathroom and how weird that is. It's like 'We expect you to be like these young, responsible young adults, but then you have to ask me to go pee."”

Michelle has students write and present "in the bag" speeches, which are when students present items from a bag that represent themselves. Michelle explained how she integrates opportunity for self-advocacy:

I've encouraged kids with autism "Maybe one of your times let it be something autism related. You can use that to each your classmates about what's going on with you...because that's the only way they're going to understand if you explain it if you're comfortable...I had a kid with Tourette's one time who got up and used that [speech] and explained about his tics. And you know what? Nobody ever looked twice at him after that.

Self-management. Erich, Erin, and Kara discussed their roles with helping students implement self-management strategies. Erich and Erin both explained how students are responsible for their own actions during their respective extracurricular activities. Erich is the teacher sponsor for student-led organizations, and he explains that the "basic expectations were that the four officers, your president, vice-president, secretary, and treasurer were present at pretty much everything." He explained that students run the meetings and make the decisions. Erich's role is to hold "the officers accountable" for the different tasks. Erin echoed a similar response. When she takes students to speech competitions, Erin stated that the students are responsible to self-manage their time and responsibilities. Erin's students are also responsible 
for signing up for times to practice with her. She explained "It's a lot of a responsibility... It's a lot of stress, and they handle it really well, and I'm very proud of them."

Time management. Kara focused on teaching students time management skills. She explained it is important that she directly teaches these skills, so students are prepared for managing their time with large projects and also studying for finals. However, Kara taught her students these skills in a relatable way to them:

I say I'm having Christmas dinner at 1:00. What has to be done by 12:30? I need the table set. At 12:20, I want the potatoes on the table, so I better start mashing at 12:10, and we go through that. And their first big project, I teach them that. I teach them [with] direct instruction how to fill out an assignment notebook and how to check off, and I basically, as their mother, will say "I will have random checks."

The random checks are an accountability measure she uses to ensure her students are implementing her time management and planning strategies.

Problem-solving. Kara, Jim, and Erin help their students learn how to problem-solve. In this example, Kara used a personal story to share her thought process with students. She was telling about how she was waiting in her car in the turn lane with her blinker on:

Here comes an older woman, and I thought "Don't you pull in there. Now, don't you do it." This is a busy, busy day. You know what she did? She did it. I say "I had some choices." My first choice was, you know, to get out and yell in her face. (She laughs) Instead, I was thinking of leaving a religious thing in her window. I had all these choices. Let's think about it realistically. Maybe she had some mobility issues and needed that spot. Maybe, she thought I was waiting, so she could get it. I said "I don't know," but I said "I finally what I did is parked down the pike there, and I decided thanks be to God 
my legs can carry me up here. And I don't know what her problem is, but it's not my problem anymore."

Although Kara is referencing this as making choices, she is really making a decision to not allow other people's choices affect her decisions. Kara also helps students problem-solve when they need to get locks off of their lockers. They problem-solve by coming to Kara and advocating for additional support. She has had students who approached her and stated "I don't know what to do, and I haven't been able to get in there for three days." Kara helps her students find a solution to their problems.

Erin relates decision making to her students being consumers who will need to buy products. They watch Shark Tank, decide if they like the product, and provide an explanation. Then, the students have to analyze how they feel about specific products and justify their decisions as to whether or not they would buy the product. Erin explained "And a lot of times, it goes back to the personality of the seller, not necessarily the product itself." Therefore, Erin encourages her students to truly think about products to decide if the product is something they should purchase. Another way in which Erin helps her students problem-solve occurs when she places them in groups and helps them work through any conflict that may arise. Erin teaches students different strategies for problem-solving:

You have a problem that you guys have to solve, and so it's how you solve it. So, we talk about different problem-solving skills. So, we talk about when it's appropriate to do like a vote or when it's appropriate when we do different, you know, adding numbers and ranking things, and then we talk about brainstorming and how important it is that every single person gets their brainstorming ideas out. 
By providing students with different strategies for problem-solving, she hopes students will more effectively work with others.

Jim explained that his art content may not help students specifically in postsecondary settings, but he explained that problem-solving is an important skill he helps students learn. He detailed his rationale for students needing to problem-solve:

When you're making something, it's not always going to work out just like you think. You're going to have to figure out why and figure out how to get it going in the right direction. And again, I think again that's the type of stuff that will help them.

Overcoming adversity. Jim, Ron, and Michelle agreed that it is important for students to have the skills to recognize and overcome adversity. Jim explained that you "need to have tough skin." He explained that it is all about how you respond to adversity. He gave this direct approach to addressing adversity: "You can either pack it up and go home, or you can fight through it and make yourself better." Ron has a similar opinion. He explained to his students that "You are not the problem...you have to learn how to play the game effectively" in order to be successful.

Michelle approached her discussion about overcoming adversity with her students in a different fashion. She explained to her students about "brick walls." She detailed the following with her class:

The brick walls are there to see how bad you want something. Are you just going to let it stop it? Are you going to go over it? Are you going to go through it? What're you going to do? And so, I have them write, you know, what are your brick walls?

She also shared with her students about her personal brick walls and how she determined if and how she would overcome her brick walls. Michelle wants her students to overcome the 
adversity that they will face in life. When asked why she taught students to recognize their brick walls, she explains that she wants them to realize that they can "Overcome it. And realize maybe what they have already overcome."

Michelle described one young lady's problem-solving approach when she needed assistance with paying for college:

One of the English teachers I was working with said that he had a girl who had been in AP Language and that she wanted to go to med school, but her parents were like "You can either go to med school in [this state], but if you go in [that state], we can't pay that extra, so she ended up talking to National Guard, and she joined National Guard to help pay. She was like "I wish somebody-you know, I know they talk to the kids on the lower end, but they don't talk to the kids who are kind of on the higher end." Michelle outlined why it is important for general education teachers to be aware of postsecondary options, so they can help all students prepare for postsecondary life.

Self-efficacy. Half of the participants discussed how they help students feel positively about their self-efficacy. Kara, Erin, and Michelle all provided specific examples of selfefficacy. Kara explained that "If they think they can succeed, then you're a big step ahead." She wants her students to be prepared and feel confident with their skills, so her students believe in themselves.

Erin also wants her students to have high self-efficacy. She provides opportunities within her classroom to promote their efficacy. She assigns students classroom roles:

The student I choose to do that, I think those are the kids that probably don't have a lot of - I think it kind of gives them like they're - they're kind of the stars of the class that day. And so, you know, those are the kids that don't generally have that, and I'm kind of 
hoping that this gives them a purpose to come to class. And they always love it—love it. It's a simple thing, you know, but a lot of them are excited that I'm letting them have their phone on their desk with their timer. But they love having - they love that responsibility. And I think for them to have positive feelings about responsibility is really important.

By giving her students roles and responsibilities in class, Erin hopes to increase her students' self-efficacy.

Michelle approaches self-efficacy in a different fashion than both Erin and Kara. Michelle shares her own personal struggles with her students. She explained that "Anxiety is a brick wall, but I've worked to overcome it. I don't let it hold me back. I don't keep—I talk about it, so you all can see those of you who struggle that I'm a happy person.” Michelle shares her own personal stories to help her students realize that they can face adversity, be happy, and have a positive feeling of their self-worth.

Psychological empowerment. Ron, Erin, and Michelle discussed psychological empowerment. Ron wants his students to get involved with their communities. Through his 20 percent project, Ron facilitates an opportunity where students can feel proud and empowered by volunteering their time to promote social good for others. Erin approaches psychological empowerment in a different manner. She explained that she wants her students to have a positive high school experience. She provides opportunities for students to have in-class responsibilities to help students find the positive aspects of school. Erin explained "Some kids just have such a negative view on high school, and so for them hopefully to be able to look back and think of some of the good things that happened." She provides opportunities for students to feel empowered. Erin wants her students to think "I have a purpose." She believes that having 
the ability to feel empowered is important. To encourage students to have positive feelings about her class, Erin also has students fill out speech reflection sheets. She explained that students typically focus on the negative aspects of their speeches, which is why Erin developed this reflection opportunity:

I also want them to see what they're doing well. Because they sit down, and they're like "Oh. I forgot to say this. I went over time" and that's the only—like I never hear a student sit down and say "Yes! I did good!" They sit down and concentrate on the negative things, and so I think it's really important for them to watch themselves, and that's why—I like—one of the questions on their self-evaluation worksheet is you have to give me three things that you did well, not just one. You have to give me three. Even if it's just: I got up, and I gave my speech. I was prepared today. Michelle takes a different approach to psychological empowerment than Erin does, but they both want students to feel good about the classwork they are doing. Michelle explained that she and her co-teacher "talk to them a lot, too, throughout the year that you can't compare your stuff to somebody else's. We are all in different places." She explains that her co-teacher drew a fence with three different sized boxes, so three children can stand on the boxes and see over the fence. She explained that in class, each person gets different supports to be successful, and each student receives what he or she needs to be successful. Therefore, students may notice they receive more or fewer supports than their peers, and that is fine. She explained the following: We'd give this one a little box. We'd give that one a bigger box, so they all can see the same thing. So, we talk about "Some of you don't need any support. Some of you need some, and some of you maybe need more, but nobody's getting - you're all seeing the same thing." 
Instead of hiding differences her students may see in class, Michelle wants her students to know that differences are okay, and every person is getting what he or she needs to be successful.

Goal-setting and attainment. Both Michelle and Erin include goal-setting components in their instruction. Erin explained that she has her students set goals. She explained the importance of goal-setting, but she also makes it fun and engaging for her students:

We set goals. We set a lot of goals, and we actually post them in my classroom. So if you were to walk into my classroom, there would be a bunch of colorful laminated pieces of paper all over the walls that say "I want to improve my eye contact" and things like that. We read an article that talks about how Olympians mentally prepare for sports, and one of them is to write goals and post them where you can see them every single day. So, from that, I have them write their goals for the class, and they had to post them in places. Some of them are on the fans, on the ceiling, and some of them are on my podium, and some of them are hanging off the desk that's directly across from them, so this is kind of craziness, but it's fun. And then they, you know, we remind them of that all the time, so setting goals is a huge thing.

Like Erin, Michelle also helps her students with long-term goal setting: I always say “Sometimes, I feel like a dream killer.” Like I had a kid one time who wanted to be a pilot, and he could not even do basic math. And I was like you struggle that fine line of reality and like he might be able to clean the airplanes. He might be able to maybe be a mechanic, but flying the plane I don't know is going to be a possibility. And he ended up, he liked art. And I was like "Why don’t you maybe do something with art?" He does graphic design now—very happy. 
Michelle helps her students find realistic postsecondary options that were based on his strengths, interests, and preferences.

Michelle also described a simple approach to goal setting. She explained that "for my seniors, goal setting is 'get that diploma." This echoes what Kara's sentiment: "Sometimes to prepare students for life after high school, you gotta get them through high school." Students may need to focus on completing their high school career in order to prepare for postsecondary life.

Self-monitoring. Erin was the only participant who specifically stated she had student self-monitor their performance. When she taught students about working groups, she explained an activity where she had students self-monitor and collect data on different group roles and member participation:

I actually do a little activity to start the group process, and I call four students into the front of the room, and I have them sit in a circle, and I give them a problem that the school wants to get a new mascot. And so, they have been chosen on the student team to figure out that mascot, and then, so they, it's like a very much like a case study, and so the class sits and watches them work out that problem. And so what I do with the other students in the classroom is I assign each student a different person in the group, and they have to tally how many times that person speaks. And then I have other students who tally every time somebody's interrupted. I have another student tally how many negative comments were made. I have another student who tallies how many positive comments were made.

After collecting the data from students working in groups, Erin teaches students how to evaluate the data they have collected. 
Self-evaluation. Erin and Jim included self-evaluation in their instruction and general classroom philosophies. Erin uses the data from the group activity to evaluate different participants' roles in the groups. She is trying to help students learn the skills, so they can selfevaluate and learn the traits necessary for functioning within a group:

Then we kind of look at that data, and we look at "ok, so so-and-so spoke the most, but who would you say is the actual leader?" And a lot of times, it is that person who did not speak the most. And it's like the middle person and so we talk about "Okay. Just because you're the leader, that doesn't mean you have to be the person who talks the whole time. You know, the leader is the person who kind of sits back and lets everybody else do the talking and then chimes in when necessary. And so, we kind of add that numeric - the numbers to it, I think a lot of things are like "Oh, interesting."

Along with Erin, Jim also discusses self-evaluation with his students. He talked about how he teaches students to self-evaluate their performance based upon their own individual progress. Jim explained that for students with disabilities, his goal is for the same as it is for his students without disabilities: "I'm trying to get every student to reach their personal best." Jim discussed that "It doesn't matter where you start. It's kind of where you finish." For all students, Jim wants his students to "finish better than you were yesterday." Jim wants students with and without disabilities to self-evaluate and recognize that they have made improvements with their skills and goals.

Self-awareness. Jim explained how he helps students understand their strengths and weaknesses. He has this conversation with students, so they understand that each person has different strengths and opportunities for improvement: “There's things that you're good at that we aren't the same. And so you have to learn that you're not good at everything." He 
challenges students to think about their strengths: "How can we better that, or how can we use what we're good at to advance ourselves?" Jim also relates having self-awareness to life after high school, encourages his students to help others, and has students plan for their dreams:

I might not draw as well as you. What can I do to increase my skills so that I can if that's what I want to do. And, in life, you're not going to be as good as somebody else or somebody else is not going to be as good as you and how can you get better or help others get better? I think that's one of the things that I really try to instill in the kids is work to where they want to be.

Along with Jim, Michelle discussed students' specific skills, strengths, and opportunities for improvement to help them become more self-aware. She referenced students' abilities to read out loud to help students recognize their differences from others:

We all are different, and some of us are good at one thing, and I talk about how like some kids as readers, they're like - they're the pretty readers. When a teacher says "who wants to read," they're like (motions to raise her hand) because they know it sounds like birds should be chirping on their shoulders, and squirrels should be tying their hair, you know, bows in their hair. It's so pretty. But if you ask those when they get done, what did they read, they have no idea. And then kids are like-some of you when you read, (read slow and choppy) it sounds real like you don't know who I, what you're reading. And I'll get to the comprehension questions with those kids and they remember everything, and I have to look back because I don't know what the details were. And the kids were likeand I'm like you're the kids that never want to volunteer because it doesn't you know sound pretty, but realize there's a trade-off for some of you. Some of you read pretty, and you comprehend well, but you're in the minority. And I was like "Am I talking to 
anybody in here," and they were like "Yeah." And I'm like "some of you are math people. Math comes to you like nothing, but when it comes to writing and grammar and English and reading and comprehension, you're lost." And they're like "yeah." And then it's the flip side, some of you are really gifted at the writing and English, and you go to math, and you die. "Yeah." And so, we just put that out kind of from the beginning and celebrate your differences. And I'm like "Look! You don't all want to be cookie cutter; you don't all want to be the same. That would be boring, so realize that we all come from different backgrounds."

Along with helping students become self-aware of their own strengths and weaknesses, Michelle discussed how she helps students to be aware of their differences relating to students' emotional well-being. She detailed how our differences cannot always be seen, but those differences exist. Michelle encouraged students to not judge others negatively based upon differences with this example:

I talk about emotional baggage, you know? If we all visibly carried our emotional baggage with us, some of you, bless your heart, wouldn't even have a little wallet. Some of you would maybe have that Nike drawstring. Some of you would maybe have a duffel bag. Some of you would have a suitcase on rollers. And some of you'd need a U-Haul. But the difference is we don't see that. You can sit next to somebody and think you know them, but you don't know what goes on when they leave this building, so be wary, be knowledgeable, and understanding of the fact that differences go beyond so much more than an IEP.

Michelle provided her reason why students should be self-aware and knowledgeable that people come from different backgrounds: 
I hope that they would always remember that because let's face it. I tell them this, too. At the end of the day, you may not remember old "Romeo, Romeo, wherefore art thou, Romeo?" But hopefully, you'd remember how to be a decent human being and to be accepting of other people. They don't have to believe the same things you believe or see things the way you see them, but you can be understanding. And that, at the end of the day, you know as well as I do, that's the most important lesson. So, I think it helps them. Michelle and Jim both took an in-classroom approach to helping students understand selfawareness. Ron, on the other hand, explained a different approach to helping students understanding self-awareness. He preferred students understand self-awareness in a larger context. Ron wanted students to understand "How are we together creating the same thing that at the same time is pushing its forces upon us, and it's a-you know-these types of things to get them to think about things that most of them have never been exposed to before." By trying to help his students become self-aware in a larger context is how he hopes they will become more involved.

\section{Authentic Teaching of Skills}

Kara, Jim, Erin, Ron, and Michelle all provided their students with an opportunity to practice skills in an authentic fashion. Kara helped students replicate experiments that they have seen. She encouraged students to make predictions and practice replicating results.

Jim, Erich, and Erin require their students to practice social skills by working in groups. Erich had students practice their communication skills with other students to improve their Spanish language skills. Jim's students practice their skills by creating create pamphlets "for people around school." They design logos and infographics and also work for the school newspaper. 
Erin, Ron, and Michelle encouraged their students to practice their skills in authentic fashion. After teaching students how to use research skills, Erin "had [students] write a letter to a state legislator" about a topic occurring in a different part of the world. They had to research a given topic and then write letters to their legislators." Ron also engaged students in authentic opportunities to practice their skills through their 20 percent project. They have a choice on what their project is. He also explained that one of the extracurricular clubs in which he is involved "did an event at [a local U.S. Representative's]" office. The students discussed a current political issue with the Representative. Ron further explained they were interviewed on a local radio station.

Michelle explained that she shared a letter that she received from her county. She explained her county is "having a writing contest that almost fits in with what we're doing, and they can enter and try to win money." This was another way in which these participants encouraged their students to practice their skills in an authentic manner.

\section{Participating in IEP Meetings}

All six participants reported participating in IEP meetings. However, only three of the six participants, Jim, Erin, and Michelle, reported being collaboratively involved within the IEP meeting. Furthermore, these same three participants were aware of transition planning occurring during their respective IEP meetings.

Jim described his active participation in the following fashion:

Often as a regular ed teacher, you have to go to an IEP meeting or transition meeting... In those meetings, you know, I'm just making recommendations based on the ability level that I've witnessed, and talk about their growth that I've seen in, in areas of that I see 
where they could excel, and then maybe that helps direct them where they could pursue interests later, later on or outside of high school.

Jim understands that a general education teacher is required to attend IEP meetings, and he is often the general educator invited to IEP meetings. He attends IEP meetings but not because he is legally obligated to attend; he attends the meetings because he wants to be there. He explained "It's not always easy to get regular ed teachers to go to the IEPs. I go to them whenever I can. I go to them because it's the least I could do." However, he does sometimes find it difficult to participate in IEP meetings because "Sometimes, I haven't had the students." Since he does not know the student prior to the meeting, he cannot offer specific information about his observations or provide specific examples of the student's strengths. Nonetheless, Jim will make general comments about topics being discussed and offer general suggestions during IEP meetings, so he can be an active participant.

Erin explained that she has not had much experience with transition planning. She indicated IEP meetings are the extent of her involvement in transition planning: "In the IEP meetings that's kind of really the only experience that I have with transition plans." She explained that she has a familiarity with attending IEP meetings because her courses are graduation requirements. Therefore, she is often invited as the general education teacher to these meetings. Erin explained that during IEP meetings, she learns about postsecondary goals for her students. As she elaborated, she enjoyed "just kind of hearing about their transition goals... what they want to do with their life and their profession." Not only does Erin learn about her students' postsecondary goals during IEP meetings, she also wants to "try to kind of integrate [students' postsecondary goals] into things." Her involvement within transition planning meetings helps 
her to collaborate with students about their futures. She gave this example about a student whose goal was to own and run her own bakery:

So when you own your own bakery, you're going to have to market your products, and you're going to have to, you know, talk to people that you're selling to. You're going to have to talk to people you're going to want to buy products from and things like that.

Erin explained that knowing students" transition plans is "very important for me to kind of make things relatable to them." Erin learned about students' postsecondary goals and integrated them into instruction.

Michelle's example demonstrated how she discussed the realistic nature of postsecondary options. Jim uses his discussion opportunities about postsecondary goals to better understand the student's goal. Once he knows what a students' postsecondary goals are, he provides example of how his content can help a student prepare for adult life:

You know, having sat through some of those meetings, where you know they say "Well what's your living plans? Do you plan on living at home, a group home, do you plan on living with your parents? Do you plan on living on your own? What?” And you know, I don't know, if some teachers would be responsive to like say "Well if John is going to live on his own, what kind of skills is he going to need to be able to live on his own?" So, if we're mixing paint you know, hey John, maybe mixing paint's kind of like mixing food. You have to have the right amount and those types of you know, those types of things... And teaching art allows me to have a lot of individual contact, I get it. Math you probably don't, science you might not as much. But, um, who knows? Who knows what you can work into some of those other classes. 
Jim demonstrated from his example that he can relate his class to students' postsecondary goals and needs. He also discussed, from his perception, that there may be opportunities for other general education teachers to incorporate transition practices in their classes.

Michelle explained that “I don't feel like there's as big of a parent component in the IEP in regards to transition." She stated that she thinks there needs to be more parental involvement not only in the development of the IEP for transition services, but they should also be involved in the implementation of IEP transition services.

Jim, Erin, and Michelle reported substantive involvement in IEPs. In contrast, Erich, Ron, and Kara reported attendance but limited involvement. Erich explained that he usually has at least one student with a disability in his Spanish I or Spanish II course. However, he explained that he did not have a student with a disability in his classes this year. Erich also explained that he has not been invited to participate in an IEP meeting for approximately three or four years.

Ron discussed his involvement at IEP meetings. Unlike Michelle, Erin, and Jim, Ron's participation was less involved. He explained that he was asked if he provided the supports listed within the IEP. Other than stating that he is providing the IEP supports, he did not believe he played a meaningful role during the meeting. He described his participation as "I just basically sat there. I don't think I've been involved at all in official transition planning." Ron was not the only participant who expressed a lack of transition planning involvement. During her involvement with secondary students' IEP meetings, Kara stated that she was not involved in transition planning because "I've never been far enough along because kids are freshmen that I teach." 


\section{Communicating}

Communication was a reoccurring theme based on findings from interviews with the participants. Communication findings were placed into two themes: 1) communication relating to all students and 2) communication specifically relating to students with disabilities.

All students. Michelle described her communicative role working with all students and their families. Sometimes, she has had to have difficult conversations with families, but she approaches her students and their families like she would approach conversations with her own family. Michelle explained that her students and their families do not get upset with her because of the following:

I have the kid's best interest at heart, and I'm not trying to hurt anybody, but sometimes you have to open your eyes and see this might be what you want, but this is not what your kid wants... You know, like, I try to hopefully be the same with my own children, you know?

Kara also communicates with her students' families. She helps advocate for her students. She wants her students' families to know about the positive work they are doing, so Kara gave this example: "The truth was I saw a side of her that her mom had not seen. You can sometimes see that kids are doing very good things. Their parents don't believe they can do that good." Kara wants to communicate these praises with families.

Kara also communicates with her students that she is there to support them. One way in which she facilitates communication between her and her students is when she makes it against the rules for students to go without lunch. Therefore, the students "have no choice but to come and ask me." Kara's students know that they have two choices: 1) ask for money to buy a meal or 2) select items from her snack drawer. Furthermore, she elaborated "I have kids that come 
back from previous years... They know 'if I am hungry, there will be something in her drawer, and she will let me have it." Kara teaches her students that "you can come to me because this is a safe place."

Kara also explained that there are also times when her students have significant support needs. Therefore, she contacts home to ensure families are aware of her concerns. Ultimately, Kara wants her students to be supported, so she explained the following: "The family life is sometimes...very hard to overcome. Hunger will override. Trauma will override. Anxiety will override a lot of what I can do." She further explained that "I can help, but I can't always fix it without special services." She has told families the following in hopes of meeting the needs of her students: "Your child is in crisis...this needs to take place. They need something beyond what I can do.” During their times of need, Kara communicates with her students' families to support and guide them. She calls families with a tentative action plan "Here's what I see. Here's what we can do. Here's what we need to work on." She wants her students and families to know that she cares and is there to help.

Both Ron and Michelle explained that they communicate home regarding activities in which their students participate. In reference to his 20 percent project, Ron explained how he communicates the importance of this project to families: "And the way I sell it to parents is that, you know, this is what Google does. They use twenty percent of their time, their employees, to do whatever they want and that's how they're innovative." Along with Ron, Michelle keeps her students' families informed on in-class activities. Prior to bringing in a guest speaker from the military to her class, she "e-mailed all the parents first and said 'Do you object to this?"” Michelle ensured that her families were aware and approved of this extra in-class opportunity. 
After high school. Jim, Ron, and Michelle all communicate with their students after they have exited high school. Although these participants communicate with their students differently, their ongoing communication helps support, encourage, and show their genuine care for their students.

After students had graduated from high school, Jim explained that he stayed in contact with students through social media. Through social media, he sees "when they post their stuff, I always talk about, you know, yeah it's great to see you're still doing your thing. Keep up the good work." This form of communication allows Jim to stay updated with his former students' progress, and he also praises their successes.

Ron also is in contact with students after they have exited high school. He shared his story about this young person who joined the military: "She came back to tell me like to confess 'I enlisted in the Navy, and are you going to be disappointed?' I was like 'No, I'm not disappointed in you. I'm just looking out for you.'" Ron's communication shows a genuine care for his students and their wellbeing in postsecondary settings.

Students with disabilities. Michelle also maintains ongoing communication with students after they have exited high school. She was, however, the only participant to provide an example of ongoing communication with a student with a disability. Michelle saw the student working in the community. She explained that he recently asked her to write him a letter of recommendation to continue his education. She explained her thoughts on the situation: "Why not? The sky is the limit. Go do it."

Communication to support students with disabilities. Erin is communicating with her administration to support her students with disabilities. She met with her building administration to try develop a new class to adequately support youth with disabilities: "We did try to get just a 
special ed speech class...that was more like interview skills and regular public speaking skills." Erin elaborated that she believed her students with 504s and IEPs would have benefited from direct instruction on those functional speaking skills. "Unfortunately that didn't happen, but we are still trying to get that happening in the future."

\section{Barriers}

Participants identified two barriers to transition planning involvement: 1) a need for greater communication from special education teachers and 2) a lack of resources.

Communication with special education teachers. Several participants wanted additional communication with special education staff. They wanted to know the about the following: a) presentation of rationales used for IEP decisions, b) identification of postschool goals, and c) communicating priority skills.

IEP rationales. Both Erin and Kara would like to know the rationales provided for decisions made with IEP decisions. Erin wants to better support her students beyond what is required through the IEP document. Erin requested professional development on supporting students with disabilities and also on disability awareness. She shared this example: "So, I'm giving this student a word bank, but I would like to know why they need a word bank." Erin wanted to use the professional development and the rationales provided for IEP decisions to make changes to her daily practices with better supporting students with disabilities. Erin stated "I think it would be beneficial to maybe get some more ideas of who those kids are and what they actually do well in and need help with.”

Kara also would like to know the rationales used to make IEP decisions. In reference to IEP decisions, Kara stated "There have been some things that have been kind of fishy." 
Regardless, she will implement the legally required IEP supports. To help her understand, she stated the following:

It might be interesting for me to hear how are we setting his goals? Why do we think the student needs to have this accommodation? Basically, I'm just told this is the accommodation. Now, let's have it. Ya know? Make it happen. So, I'm basically told what needs to be made to happen, but I don't always have the reasoning behind it. Kara hopes to contribute meaningfully to the IEP team by providing data and offering updates on specific aspects of students' IEP. To elaborate upon her thoughts, Kara shared the following:

If I'm told that Blue Bonnet needs to have all of her math tests cut up into seven parts or whatever... Why? Tell me why? And I know the benefit of it now that I'm older, but as a younger teacher I'm not sure that I understood everything. I would just do it because I was told to do it. So, maybe, some rationale, some input, and say "Okay. Now, the last twelve weeks, I've cut up Old Blue Bonnet's test, and she's put them in her back pocket. So, that's not effective. I'd like to say: "I've tried this, and now this is what I can tell you about it."

Kara would like the opportunity to express how the accommodations are being used within her classroom. She stated that she would like an opportunity to give input on accommodations: "Yes it works. No it doesn't and here's why."

Identification of postschool goals. Along with wanting to know about the rationales used for IEP decision making, Jim, Kara, and Erin wanted information about students' postschool goals. Erin explained that she appreciated "just kind of hearing about their transition 
goals" in order to integrate components of students' goals into her classroom. Kara and Jim also wants to know about students' postschool goals.

Priority skills. By knowing Kara's students' postschool goals, she is able to learn about identified priority skills on which the students should focus. She detailed this scenario:

If this person is college bound, here's this person's deficit. Here's what we really need to see this person get good at if we are going to see the possibility of them going to a community college or a four-year college, and we'd really like you to make sure [the student] is doing these things.

She provided this rationale for knowing students' priority skills:

He's got to learn to do it because to be successful— One or two things a year and then everybody does it every year. All the teachers freshman level do that. I think that would make sense. Don't you?

Resources. A lack of resources was another commonly discussed theme amongst participants. Erich, Ron, and Erin all described a lack of resources. However, only Ron and Erin identified a lack of resources affecting the supports they are able to provide to students.

Erich explained the following:

I think that, that we do, for being a small school, with as short on resources as we are, both for being a small school and with the lack of help that we're getting from [the state capital], I think we do a pretty good job of making sure that their needs are met. Ron identified a lack of resources as affecting his ability to support students with disabilities as they prepare for adult life. His lack of resources were not at the local level. He wanted systemic changes to occur, including providing all individuals with free healthcare, free 
college, and guaranteed working wages. He explained the he believed "We need systemic change at the national level and the state level."

The resource that Erin identified was additional time to learn about her students and to effectively support her students. She described the yearly training she receives on students with disabilities:

A lot of times the quote unquote training that they give us is a PowerPoint presentation, and they say “Okay—here's your kid...Okay. Here's all your IEPs for the semester. And then you flip through them and you're like "Alright. Here we go." I think it would be beneficial to maybe get some more ideas of who those kids are and what they actually do well in and need help with.

\section{Summary}

Based on the findings from the participants, these general education teachers clearly identified how they help prepare all students for adult life. These teachers facilitate multiple transition opportunities and experiences for their students with and without disabilities. Broad areas in which these participants identified their involvement with transition were as follows: a) having desired student outcomes, b) exposing students to postsecondary options and helping them set goals, c) facilitating opportunities for students to develop needed skills for adult life, d) participating in IEP meetings, and e) communicating and collaborating. 


\section{CHAPTER V: DISCUSSION}

\section{Findings}

This study was conducted to examine general education teacher's perceptions of their roles in preparing all youth, including those with disabilities, for adult life. The responses to the interview questions indicate that these general education teachers in fact play a large role in supporting all youth during the transition process to postsecondary life. Overall, the data confirm and extend the findings of previous studies conducted on transition practices to include general education teachers. However, it is important to note that minimal previous research on general education teachers' involvement in transition has been conducted.

\section{Benefits}

These participants' transition involvement will likely benefit their students, as they transition out of high school. These general education teachers are teaching functional skills, self-determination, engaging in transition activities, and discussing all postsecondary outcome areas.

Functional skills. These six participants were responsible for teaching academic content, but they also integrate functional skills within their respective classes. According to Wagner, Newman, Cameto, and Levine (2003), students with disabilities take an average of $60.2 \%$ of their classes in general education settings. Also, $27.2 \%$ of youth with disabilities take courses completely in general education settings (Wagner, et al., 2003). All six participants incorporated functional skills for all students and for students with disabilities, which aligns with the $68.1 \%$ (all students) and $68.3 \%$ (students with disabilities) who learn life skills within academic settings. Social skills instruction and self-determination skills are specifically noteworthy; both of which are listed by Test, Mazzotti, Mustian, Fowler, Hortering, and Kohler 
(2009) as evidence-based predictors that lead to improving outcomes for students with disabilities. Although Eisenman and Celestin (2012) explained that social skills are important because "Others are more likely to acknowledge and engage someone if that person displays social behaviors that are seen as normative social interactions with the person [and] are viewed positively (or at least not negatively)" (p. 223). Wagner et al. (2003) commented that students with disabilities are less likely to learn life skills material in language arts and social studies classes. However, in this study, the participants who taught English (Erin and Michelle) and the participant who taught U.S. History and Sociology (Ron) reported integrating functional skills into their classrooms. Based on these participants' practices, all students, including those with disabilities, benefitted because they learn functional skills needed for adult life.

Self-determination. Self-determination is an evidence-based predictor of postsecondary success for youth with disabilities (Test, Mazzotti, et al., 2009). The six general education teachers in this study taught different components of self-determination. This is critical because, as Wehmeyer and Schwartz explained, self-determination helps improve an individual's quality of life (1996). Wehmeyer, Field, and Thoma (2012) wrote the following:

That self-determination is an important focus if students with disabilities are to achieve more positive transition-related outcomes is predicated on an assumption that selfdetermination and positive transition-related outcomes are, in fact, causally linked—an assumption supported by a growing literature base (p. 174-175).

Clearly, self-determination is important for youth with disabilities to be successful in adult life, but it was particularly interesting to see how substantively these participants included selfdetermination within their respective settings. 
Shogren, Wehmeyer, and Lane (2016) provided suggestions for incorporating interventions that could be used within Multi-Tiered System of Supports, which is part of general education, to promote the self-determination for all students, including those with disabilities. Shogren et al. further wrote "The ultimate goal of these supports is to promote positive academic, social, and behavioral outcomes in school, preparing students to meet the demands of society, including the need to be self-regulated, goal-directed learners" (p. 214). Additionally, Shogren et al explained (2016) "In both the general and special education field, promoting selfdetermination has been identified as a vehicle to motivate students and raise expectations, creating opportunities for students to learn skills and begin to perceiving themselves as selfregulated, goal-oriented learners" (p. 217).

Because of the possibility self-determination has for improving students' postschool lives, it is promising that these general educators incorporate self-determination opportunities for all students, including those with disabilities. For example, four participants integrated opportunities for self-advocacy. As Wehmeyer and Field (2007) wrote:

All students, but particularly perhaps students with disabilities, need to learn the skills to advocate on their own behalf. To be an effective self-advocate, students have to learn both how to advocate and what to advocate for (p.34).

Participants included multiple opportunities for students to practice self-advocacy. Two participants required students to advocate for makeup work. One of these participants also encouraged her students to self-advocate for their disability and share how it affects them with peers. One participant requires students to advocate for help from each other prior to asking him for help, and one teacher encouraged students to advocate for "the right thing to do." These skills will benefit students during and after high school. 
Half of the participants described their students' involvement with self-management. Wehmeyer and Field (2007) explained that there is research that links the positive outcomes with self-management and self-regulation. Through extracurricular opportunities, three participants required students to self-manage their involvement within certain aspects of those activities. Kara directly teaches students how to manage their time, which is a component of selfmanagement. These teachers are including these functional practices into their coursework to help students be successful in postsecondary life.

Wehmeyer and Field (2007) suggested infusing problem-solving instruction into curriculum, which is exactly what four participants described. Erin teaches her students strategies for problem-solving. Jim described how he infuses problem-solving opportunities within their respective content. Kara helps students problem-solve with school-related issues like getting locks off of lockers or not having money for lunch. Michelle helps her students problem-solve how they can overcome adversity. These educators are integrating problemsolving opportunities into curriculum and daily school life to help students be better prepared for adult life.

People with a positive self-efficacy believe that they can be successful with achieving goals (Wehmeyer \& Field, 2007). They explained "Individuals also have efficacy expectations, which are beliefs about the probability of the performance of a given behavior leading to the desired outcome" (Wehmeyer \& Field, 2007, p. 35). Three participants described how they helped students develop a positive sense of self-efficacy. Kara explained "If they think they can succeed, then you're a big step ahead." Erin integrates opportunities for students to develop positive self-efficacy into instruction, and Michelle shares her own experiences to help students 
develop a positive sense of efficacy. These participants are teaching self-efficacy, which could help students obtain their future goals.

Psychological empowerment is another critical component of being a self-determined person:

People who are self-determined are psychologically empowered based on the beliefs that (a) they have the capacity to perform behaviors needed to influence outcomes in their environment, and (b) if they perform such behaviors, anticipated outcomes will result (Wehmeyer \& Field, 2007, p. 5).

Three participants discussed psychological empowerment. Ron, Erin, and Michelle all encouraged opportunities for students to develop psychological empowerment. Ron wanted students to feel empowered to make change within their communities. Erin helps her students feel needed and that they have a purpose. Michelle encourages her students to not compare themselves with one another because each person receives the supports they need for her class. These teachers are helping their students develop psychological empowerment, which will help students have more successful adult lives.

If a person sets goals, the more likely that person is to achieve the goals he or she sets (Wehmeyer \& Field, 2007). Three participants explained how they help students with goalsetting and attainment. Erin directly instructs goal-setting in her classroom, and her students place goals around her classroom. Michelle described how she helped students with disabilities plan their postsecondary goals. Also, Michelle, along with Kara, helps students realize that sometimes their goal must be getting their high school diploma. By helping their students set goals, these teachers are increasing the likelihood that their students will attain their goals. 
Erin was the only person who stated that she explicitly taught her students to self-monitor their in-class performance. According to Wehmeyer and Field (2007), self-monitoring is one component of self-evaluation, which involves individuals "making a judgement as to progress toward a goal" (p. 93). Erin's description of self-monitoring directly related to these selfmonitoring benefits listed by Wehmeyer and Field: a) helping students better understand their own behavior, b) gave students immediate feedback, and c) students worked together cooperatively. Erin is providing direct instruction on self-monitoring, which will benefit all of her students.

Self-awareness is another component of self-determination that was discussed by these participants. Self-awareness was defined in the following fashion:

For students to become more self-realizing, they must possess a reasonably accurate understanding of their strengths, abilities, unique learning and support needs, and limitations. Further, they must know how to utilize this understanding to maximize success and progress (Wehmeyer \& Field, 2007, p. 35).

Jim and Michelle both helped students develop self-awareness through in-class activities. They explained it was important for students to realize, accept, and learn how to use their differences to better themselves. Ron also encouraged students to develop self-awareness of society and understand how it affects them. These general education teachers are, as Wehmeyer and Field suggested, helping students to learn about their strengths, areas of growth, unique support needs, and helping students to maximize their opportunities for postsecondary success.

Although these general education teachers may not be familiar with the selfdetermination literature, they still recognize the importance of teaching self-determination skills and components. Components of self-determination were reflected in course expectations, 
directly instructed, and taught situationally. Because self-determination is a predictor of postsecondary success (Test, Mazzotti, et al., 2009), it is promising to see these general educators teaching all students, including those with disabilities, these particular skills. Although these general education teachers are teaching self-determination skills, Test, Bartholomew, and Bethune (2015) suggested that schools should self-assess their implementation of all the different predictors identified by Test, Mazzotti et al. (2009) of which self-determination in one predictor. Test, Bartholomew, et al. explained that school administrators could use this self-assessment data to improve the transition services provided at their respective schools.

Transition activities. These participants explained how they facilitated opportunities for their students to explore postsecondary options. Student involvement is critical to transition planning (Kohler \& Field, 2003; Wehmeyer \& Webb, 2012). One way to help students participate in their transition planning is for them to know their options. These participants helped students set goals, provided exploration opportunities, participated in IEP meetings, and helped students by giving general guidance. Although the type of support varied between participants, the student support provided is also a predictor of postsecondary success (Test, Mazzotti, et al., 2009)

Goal setting. Typically, teachers examine students' postsecondary goals and the "coordinated set of activities" as required by IDEA (2004). Regardless of these mandates, Kara and Michelle have focused on students finishing high school, which could be considered atypical and not appropriate planning for postsecondary life. However without a diploma, students could potentially be at a disadvantage to those with their diploma. Kortering (2012) explained that 
when students who dropout of high school are compared to peers who earned their high school diploma, the student who dropped out earned about $\$ 9,500$ less annually.

Jim and Michelle involve families in transition planning, which was listed as a needed component for transition success (Kohler, 2003; Wehmeyer and Webb, 2012). Parental involvement was also an identified predictor of postsecondary success (Test, Mazzotti, et al., 2009). Wehmeyer and Webb (2012) further explained family involvement was "desired, needed, and crucial" (p. 8). Michelle helps her students advocate with their families for postsecondary goals that include their own preferences and interests, which was another guiding principal noted by Wehmeyer and Webb (2012). Additionally, considering students' wants and interests in postsecondary planning is also legally required by IDEA (2004). It is interesting that these participants help ensure schools are compliant with that transition mandate.

Postsecondary exploration. Multiple participants encouraged students to explore their postsecondary options. Ron suggests that his students visit colleges during high school, and Connor (2012) explained that students with disabilities "who visit college campuses describe their experiences as valuable to understanding the academic differences between both settings" (p. 19). College visits are only one way to explore postsecondary options.

Teachers can help students learn about postsecondary options by including guest speakers into their curriculum. Kohler and Greene (2004) suggested that preservice special educators learn from guest speakers about community agencies and their respective transition services. If guest speakers are beneficial for preservice educators, could they not be beneficial for students still exploring their postsecondary options? If so, Michelle is preparing her students for adult life by inviting speakers from multiple community agencies into her classroom to speak with her students. 
IEP meeting involvement. Legislation mandates general education involvement in the IEP and several scholars (e.g., Hughes and Carter, (2011); Morningstar, et al., 2012; Test, et al., 2015; Thomas and Dykes, 2011) have noted the importance of general education involvement. Findings from this study suggest limited involvement but also suggest an openness to more extensive involvement. For example, Kara wants to participate in the decision-making process for students with IEPs. She and Erin want rationales about IEP decisions. It is interesting to note that some participants play an active role in their students' IEPs, while others do not feel like valued members of their IEP teams. Lazaroff (2013) explained that as required IEP team members, general education teachers should know about their students' transition plans. Participants in this study who have active roles during IEP meetings clearly added substance and purpose to the students' transition plans. Those who had passive participation did not harm students' transition plans; nonetheless, they did not contribute to postsecondary planning either. In either situation, the participants clearly learned about students' transition plans, as Lazaroff suggested. With these participants, there is a definite difference between knowing about transition plans and engaging as active participants, and some of these participants want to be actively involved in the IEP process.

General guidance. Ron shares with his students that he should have dropped out of college and started a band. This raises a specific question that should be asked: "When is it okay for young adults to wander through their postsecondary options?" Our field pushes the importance of clear postschool goals. However, these general education teachers, who clearly have a unique understanding of kids, see it differently. Ron and Michelle believe that it is acceptable for students to continue exploring options upon exiting high school and not have a set plan for postsecondary life. This is an interesting idea for our field to explore. 
Postsecondary outcome areas. When asked about how their content relates to adult life, all six participants explained how their content does in fact relate to adult life. They most commonly discussed employment and postsecondary education/training opportunities. However it is particularly noteworthy that Jim specifically addresses independent living outcomes for his students with disabilities. However, he is not the only general education participant who addresses the independent living outcome area. Ron also shared with his students about how he explored non-traditional temporary living arrangements, including staying with friends while exploring his postsecondary options. He also encourages his students, through the use of his 20 Percent project, to get involved within their community. Community involvement is another aspect for consideration within the independent living domain. This is interesting because independent living outcomes are not addressed as often in the scholarly literature as employment and education or training are. Perhaps some may view independent living outcomes as less important than employment and education or training. Nonetheless, a few participants discussed independent living options for all youth, including those with disabilities.

\section{Challenges}

Special education teachers and transition professionals have explained that they feel unprepared or underprepared to serve youth with disabilities for postsecondary life (Blanchett, 2001; Benitez, Morningstar, \& Frey, 2009; Mazzotti \& Plotner, 2016; Plotner, Trach, \& Strauser, 2012). Some participants echoed that they too felt underprepared to serve transition-aged youth with disabilities as they enter into postsecondary settings.

A lack of communication. Kara wished that her special education colleagues would share transition best practices with her, so she can support her students. Erin and Kara, like Plotner, et al.'s participants, believe that there is not enough communication to collaborate 
effectively to supports students as they enter adult life. Furthermore, Kara would like the opportunity to contribute data and experiences about her students to update their IEPs. Test, Bartholomew, et al (2015) explained that educators must understand "how practices can support student skill development” (p. 266). They also encouraged administrators to familiarize themselves with predictors that lead to postsecondary success in order to guide and change school policy. Open communication about these practices could have potentially empowered Kara and Erin to better support their students.

A lack of training. Only one participant explicitly noted a need for additional training in transition. However, that participant expressed interest in more than a PowerPoint presentation. Like participants in Blanchett (2001) and Lazaroff (2013), Erin sees a need for more effective training. Blanchett (2001) also explained that trainings often tend to occur after instruction begins, as opposed to before its implementation.

Also, Kara explained that her students were too young to be involved in transition planning because they are freshmen, revealing limited knowledge about transition requirements. This is another example of a need for additional training on transition. In her state, students are required to have a transition plan in IEPs for students who will turn 14.5 years of age. Therefore, her students should, in fact, have a transition plan. Basic transition planning requirements and training could benefit all teachers who work with students with disabilities.

A lack of resources. A lack of resources is another problem facing these general education participants, which was similar to previous research (Blanchett, 2001; Mazzotti \& Plotner, 2016). However, Blanchett and Mazzotti and Plotner's participants were not general education teachers; therefore, it is not surprising that these participants described different resource-related needs. Different participants identified different needs, including a need for 
systemic change, additional time to know students as people, and disability-awareness needs. Only one participant expressed that there was no need for additional transition supports or training.

\section{Conclusions}

Researchers have documented and discussed students with disabilities' postsecondary outcomes (Benitez, et al., 2009; Blanchett, 2001; Bouck, 2012; Bouck \& Joshi, 2012; Carter, et al., 2013; Hughes \& Carter, 2011; Mazzotti \& Plotner, 2016; Mustian, et al., 2012; Plotner, et al., 2012; Plotner, et al., 2016; Test, et al., 2015; Test, Mazzotti, et al., 2009). Thomas and Dykes (2011) suggested including general education within the transition discussion. Morningstar, Bassett, Kochlar-Bryant, Cashman, and Wehmeyer (2012) also wrote that reforms must begin with including both general and special education teachers working collaboratively. Test, Bethune, et al (2015) wrote "we believe that all students are general education students first and that general educators need to know about [evidence-based practices] and predictors for their students with disabilities" (p. 269). By giving general education teachers a substantive role in the transition process for all youth, including those with disabilities, these outcomes could possibly improve. These participants have engaged in transition activities that help all students, including those with disabilities, prepare for adult life. Kohler and Field (2003) explained the following:

The concept of normalization has been a central construct in special education and disability services for many years...The normalization principle has been the driving force behind the least restrictive environment provisions of special education legislation and the resulting focus on mainstreaming in themed 1980s and inclusion in the 1990s....Effective transition practices emphasize the development of practical life skills 
that are geared toward the goals and aspirations of individual students. This emphasis on practical life skills evolved to help ensure meaningful community participation in typical settings. In other words, a primary goal of transition-focused education is to promote and facilitate normalization in postschool life.

Have these general education participants truly provided opportunities to their students with and without disabilities to help them achieve the normalization to which Kohler and Field (2003) referred? These participants have, in fact, facilitated opportunities for all students to prepare for life as productive and successful members of society. These general education teachers have taught important self-determination and functional skills, designed instruction to relate to adult life, and helped students participate in postsecondary exploration opportunities. Even without formal transition training, these general education teachers clearly described the substantive roles they have in preparing all students for adult life.

\section{Limitations}

There are multiple limitations that should be considered when analyzing the results of this study. First, the general education teacher participants agreed to meeting with me to discuss transition for all students, including students with disabilities. Perhaps these participants were predisposed to thinking about how they help prepare their students for adult life.

Next, the participants were identified through the use of convenience sampling. The participants lived worked within 45 miles of my hometown. Therefore, the population size represents only a small portion of one Midwest state, and the results' transferability should be considered within this context.

Also, I received my CITI training certification and was guided in the development of my interview protocol from my thesis chair and thesis committee. Confirmability measures 
including member checks were used. However, my lack of experience interviewing participants should also be noted as a potential limitation.

Because this was an exploratory study, participants taught different content areas and high school students from $9^{\text {th }}$ grade until age 22. Participants were not selected based upon content area, student's grade, or student's age.

\section{Implications for Future Research}

Based on this study's findings, a basic examination of general education teachers' perceptions of their transition practices were examined. Any replication of this study would have different participants who could have different insights on the importance of preparing students for adult life. Also, a larger number of participants may allow examination related to geography (rural or urban), content area, and grade-level taught.

Future researchers should focus on collecting specific data on general education teachers'

roles in the transition process. By better understanding general education teachers' specific roles in transition, all students could potentially benefit and possibly have improved postsecondary experiences.

This study created additional questions that may need to be answered to truly understand general education teachers' involvement in transition. First, how effective are the attempts to address transition for youth with and without disabilities by general education teachers?

Next, what communication occurs between general education teachers and special education teachers? Future researchers could analyze how this vital information about in-class practices is shared between general education and special education teachers.

All participants described their involvement and practices that relate to transition. However, some participants took more active roles in providing transition opportunities for their 
students, while some participants took a smaller role. In the future, researchers may want to focus on the differences that lead general education teachers to be more actively involved in transition planning, as opposed to the teachers who take a smaller role in planning for students' futures.

Lastly, future researchers should examine what can be done at the college level to prepare in-service teachers for supporting the transition of all youth to postsecondary life. This potential study should include both general education preparatory programs and special education programs to identify the similarities and differences between programs. Perhaps this information could be used to inform college instruction and better prepare all pre-service teachers for working with transition-aged students.

\section{Implications for Practice}

First, general education teachers and special education teachers need to communicate to effectively support transition practices for all youth, including those with disabilities. General education and special education teachers must communicate with one another about students' postsecondary goals. General education teachers could have undue difficulty supporting their special education colleagues when they are unaware of students' postsecondary goals. Special education teachers should inform their general education counterparts of the specific skills that students should improve to experience postsecondary success.

Next, special education teachers need to communicate important transition practices that should be used to facilitate successful transitions. If general education teachers are not taught about transition at the pre-service level and are only given trainings that are not applicable to their students, how can they be expected to know what practices should and should not be implemented? 
Perhaps, this is an opportunity for general and special education teacher preparation programs to provide additional trainings to pre-service teachers. Benitez et al (2009) found that only half of their respondents received one to four courses during undergraduate or graduate school.

After providing training to general education teachers about best transition practices, they should share with their special education colleagues about the practices they use that foster positive postsecondary results. Including general education teachers in the discussion of transition could help all students better prepare for life after high school. It is also critical that teachers continue discussing new practices and maintain open communication in order to provide students with additional opportunities to prepare for adult life.

With this information, special education teachers must remember that an IEP is a document that should updated throughout the school year. A transition plan is not a piece of paper that gets updated in a meeting and then is not looked at for another year. Special education teachers must ensure they are documenting and updating transition plans to accurately reflect the services students receive.

General education teachers should learn the basic components of transition at the preservice level. They should have a basic awareness of the IEP-required ages. For example, they should know that students should prepare for a transition plan by the time they are 14.5 years of age in this state.

Lastly, general education teachers should receive instruction at the pre-service level on incorporating self-determination skills into their content and curriculum. General education teachers should also learn about the functional skills that lead to better postsecondary outcomes. 
Lastly, they should also learn at the pre-service level how to incorporate opportunities for disability awareness within their content. 


\section{REFERENCES}

Bakken, J. P. (2015). Rationale for interdisciplinary/multidisciplinary relations in special education. In Bakken, J. P. (Ed.) \& Obiakor, F. E. (Ed.), Interdisciplinary connections to special education: Important aspects to consider (pp. 1-12). Bingley, United Kingdom: Emerald Group Publishing Limited.

Benitez, D. T., Morningstar, M. E., \& Frey, B. B. (2009). A multistate survey of special education teachers' perceptions of their transition competencies. Career Development for Exceptional Individuals, 32, 6-16.

Blanchett, W. J. (2001). Importance of teacher transition competencies as rated by special educators. Teacher Education and Special Education, 24, 3-12.

Bouck, E. C. (2012). Secondary students with moderate/severe intellectual disability: Considerations of curriculum and postschool outcomes from the National Longitudinal Transition Study-2. Journal of Intellectual Disability Research, 56, 1175-1186.

Bouck, E. C., \& Joshi, G. (2012). Functional curriculum and students with mild intellectual disability: Exploring postschool outcomes through the NLTS2. Education and Training in Autism and Developmental Disabilities, 47, 139-153.

Brantlinger, E., Jimenez, R., Klingner, J., Pugach, M., \& Richardson, V. (2005). Qualitative studies in special education. Exceptional Children, 71, 195-207.

Cantu, D. A. (2015). Role of general educators in a multidisciplinary team for learners with special needs. In Bakken, J. P. (Ed.) \& Obiakor, F. E. (Ed.), Interdisciplinary connections to special education: Important aspects to consider (pp. 35-57). Bingley, United Kingdom: Emerald Group Publishing Limited. 
Carter, E. W., Brock, M. E., Bottema-Beutel, K., Bartholomew, A., Boehm, T. L., \& CeaseCook, J. (2013). Methodological trends in secondary education and transition research: Looking backward and moving forward. Career Development and Transition for Exceptional Individuals, 36, 15-24.

Carter, E. W., Lane, K. L., Pierson, M. R., \& Glaeser, B. (2006). Self-determination skills and opportunities of transition-age youth with emotional disturbance and learning disabilities. Council for Exceptional Children, 72, 333-346.

Creswell, J. W. (2002). Educational research: Planning, conducting, and evaluating quantitative and qualitative research. Upper Saddle River, NJ: Pearson Education.

Connor, D. J. (2012). Helping students with disabilities transition to college: 21 tips for students with LD and/or ADD/ADHD. TEACHING Exceptional Children, 44, 16-25.

Eisenman, L. T., \& Celestin, S. A. (2012). Social skills, supports, and networks in adolescent transition education. In M. L. Wehmeyer \& K. W. Webb Editor (Eds.), Handbook of adolescent transition education for youth with disabilities (223-232). New York, NY: Routledge.

Farnsworth, C. (2006). Regular education teachers formulating special education plans: M. L. v. federal way school district and the IDEA [notes]. Brigham Young University Education and Law Journal, 2006, 639-660.

Gersten, R., Fuchs, L. S., Compton, D., Coyne, M., Greenwood, C., \& Innocenti, M. S. (2005). Quality indicators for group experimental and quasi-experimental research in special education. Exceptional Children, 71, 149-164.

Glaser, B. G., \& Strauss, A. L. (1967). The discovery of grounded theory. Chicago, IL: Aldine. 
Hughes, C., \& Carter, E. W. (2011). Transition supports: Equipping youth for adult life. Journal of Vocational Rehabilitation, 35, 177-180.

Illinois State Board of Education (2012). State Graduation Requirements. Retrieved from http:// http://www.isbe.net/news/pdf/grad_require.pdf

Individuals with Disabilities Education Act, 20 U.S.C. $§ 1401$ et seq. (1990).

Individuals with Disabilities Education Act, 20 U.S.C. §1401 et seq. (1997).

Individuals with Disabilities Education Improvement Act, 20 U.S.C. §1401 et seq. (2004).

Kohler, P. D. (1993). Best practices in transition: Substantiated or implied? Career Development for Exceptional Individuals, 16, 107-121.

Kohler, P. D., \& Field, S. (2003). Transition-focused education: Foundation for the future. The Journal of Special Education, 37, 174-183.

Kohler, P. D., \& Greene, G. (2004). Strategies for integrating transition-related competencies into teacher education. Teacher Education and Special Education, 27, 146-162.

Kortering, L. (2012). School completion and adolescent transition education. In M. L. Wehmeyer \& K. W. Webb Editor (Eds.), Handbook of adolescent transition education for youth with disabilities (208-222). New York, NY: Routledge.

Landmark, L. L., Ju, S., \& Zhang, D. (2010). Substantiated best practices in transition: Fifteen plus years later. Career Development for Exceptional Individuals, 33, 165-176.

Lazaroff, K. C. (2013). A study of teachers' perceptions of school-level factors affecting transition services (Doctoral dissertation). Retrieved from Proquest. (3568876)

Lehmann, J., Cobb, B., \& Tochterman, S. (2001). Exploring the relationship between transition and educational reform initiatives. Career Development for Exceptional Individuals, 24, $185-198$. 
Li, J., Bassett, D. S., \& Hutchinson, S. R. (2009). Secondary special educators' transition involvement, Journal of Intellectual \& Developmental Disability, 34, 163-172.

Mazzotti, V. L., \& Plotner, A. J. (2016). Implementing secondary transition evidence-based practices: A multi-state survey of transition service providers. Career Development and Transition for Exceptional Individuals, 39, 12-22.

McLeskey, J., Landers, E., Hoppey, D., Williamson, P. (2011). Learning disabilities and the LRE mandate: An examination of national and state trends. Learning Disabilities Research, 26, 60-66.

Merriam, S. B. (2001). Qualitative research and case study applications in education. San Francisco, CA: Jossey-Bass.

Morningstar, M. E., Bassett, D. S., Kochlar-Bryant, C., Cashman, J., \& Wehmeyer, M. L. (2012). Aligning transition services with secondary education reform: A position statement of the division on career development and transition. Career Development and Transition for Exceptional Individuals, 35, 132-142.

Mustian, A. L., Mazzotti, V. L., Test, D. W. (2012). Disseminating evidence-based practices in secondary transition. Journal of Positive Behavior Interventions, 15, 197-204.

National Center for Educational Statistics (2016). Fast facts. Retrieved from https://nces.ed.gov/fastfacts/display.asp?id=59

National Technical Assistance Center on Transition (2016). Effective practices and predictors matrix. Retrieved from http://www.transitionta.org/sites/default/files/EBPP_Matrix_Links_3.16.pdf

Newman, L., Wagner, M., Cameto, R., \& Knokey, A.-M. (2009). The post-high school outcomes of youth with disabilities up to 4 years after high school. A report of findings from the 
National Longitudinal Transition Study-2 (NLTS2) (NCSER 2009-3017). Menlo Park, CA: SRI International. Available at www.nlts2.org/reports/2009_04/nlts2_report_2009_04_complete.pdf.

Newman, L., Wagner, M., Huang, T., Shaver, D., Knokey, A.-M., Yu, J., Contreras, E., Ferguson, K., Greene, S., Nagle, K., \& Cameto, R. (2011). Secondary school programs and performance of students with disabilities. A special topic report of findings from the National Longitudinal Transition Study-2 (NLTS2) (NCSER 2012-3000). U.S.

Department of Education. Washington, DC: National Center for Special Education Research. Menlo Park, CA: SRI International. Available at www.nlts2.org/reports/2011_11/nlts2_report_2011_11_rev30113_complete.pdf.

Newman, L., Wagner, M., Knokey, A.-M., Marder, C., Nagle, K., Shaver, D., Wei, X., with Cameto, R., Contreras, E., Ferguson, K., Greene, S., and Schwarting, M. (2011). The post-high school outcomes of young adults with disabilities up to 8 years after high school. A report from the National Longitudinal Transition Study-2 (NLTS2) (NCSER 2011-3005). Menlo Park, CA: SRI International. Available at www.nlts2.org/reports/ No Child Left Behind Act of 2001, U.S.C.A §155, et seq. (2002).

Plotner, A. J., Mazzotti, V. L., Rose, C. A., \& Carlson-Britting, K. B. (2016). Factors associated with enhanced knowledge and use of secondary transition evidence-based practices. Teacher Education and Special Education, 39, 28-46.

Plotner, A. J., Trach, J. S., \& Strauser, D. R. (2012). Vocational rehabilitation counselors' identified transition competencies: Perceived importance, frequency, and preparedness. Rehabilitation Counseling Bulletin, 55, 135-143. 
Powers, K. M., Gil-Kashiwabara, E., Geenen, S. J., Powers, L. E., Balandran, J., \& Palmer, C. (2005). Mandates and effective transition planning practices reflected in IEPs. Career Development for Exceptional Individuals, 28, 47-59.

Sanford, C., Newman, L., Wagner, M., Cameto, R., Knokey, A.-M., and Shaver, D. (2011). The post-high school outcomes of young adults with disabilities up to 6 years after high school. Key findings from the National Longitudinal Transition Study-2 (NLTS2) (NCSER 2011-3004). Menlo Park, CA: SRI International. Available at www.nlts2.org/reports/

School-to-Work Opportunities Act, Public Law 103-239, 108 Stat 568, May 4, 1994, (20 U.S.C.6 101-6235). Retrieved from http://www2.ed.gov/pubs/Biennial/95 96/eval/41097.pdf

Shifrer, D., Callahan, R. M., \& Muller, C. (2013). Equity or marginalization?: The high school course-taking of students labeled with a learning disability. American Educational Research Journal, 50, 656-682.

Shogren, K. A., Wehmeyer, M. L., \& Lane, K. L. (2016). Embedding interventions to promote self-determination within multitiered systems of supports. Exceptionality, 24, 213-224.

Test, D. W., Mazzotti, V. L., Mustian, A. L., Fowler, C. H., Kortering, 1, \& Kohler, P. (2009). Evidence-based secondary transition predictors for improving postschool outcomes for students with disabilities. Career Development for Exceptional Individuals, 32, 160-181.

Test, D. W., Fowler, C. H., Richter, S. M., White, J., Mazzotti, V., Walker, A. R., ...Kortering, L. (2009). Evidence-based practices in secondary transition. Career Development for Exceptional Individuals, 32, 115-128. 
Test., D. W., Bartholomew, A., \& Bethune, L. (2015). What high school administrators need to know about secondary transition evidence-based practices and predictors for students with disabilities. NASSP Bulletin 99, 254-273.

Thomas, S. B., \& Dykes, F. (2011). Promoting successful transitions: What can we learn from RtI to enhance outcomes for all students? Preventing School Failure, 55, 1-9.

Wagner, M., Newman, L., Cameto, R., Garza, N., and Levine, P. (2005). After high school: A first look at the postschool experiences of youth with disabilities. A report from the National Longitudinal Transition Study-2 (NLTS2) Menlo Park, CA: SRI International. Available at www.nlts2.org/reports/2005_04/nlts2_report_2005_04_complete.pdf.

Wagner, M., Newman, L., Cameto, R., Levine, P., \& Marder, C. (2003). Going to school: Instructional contexts, programs, and participation of secondary school students with disabilities. A report from the National Longitudinal Transition Study-2 (NLTS2). Menlo Park, CA: SRI International. Available at www.nlts2.org/reports/2003_12/nlts2_report_2003_12_complete.pdf.

Wehmeyer, M. \& Schwartz, M. (1996). The relationship between self-determination and quality of life for adults with mental retardation, Education and Training in Mental Retardation and Developmental Disabilities, 33(1), 3-12.

Wehmeyer, M. L., Field, S., \& Thoma, C. A. (2012). Self-determination and adolescent transition education. In M. L. Wehmeyer \& K. W. Webb Editor (Eds.), Handbook of adolescent transition education for youth with disabilities (171-190). New York, NY: Routledge. 
Wehmeyer, M. L., \& Webb, K. W. (2012). Self-determination and adolescent transition education. In M. L. Wehmeyer \& K. W. Webb Editor (Eds.), Handbook of adolescent transition education for youth with disabilities (3-10). 


\section{APPENDIX: INTERVIEW PROTOCOL}

The appendix is a list of my interview questions.

1. Tell me a little about what you do.

2. How do you envision your role in preparing your students for life after high school?

a. If they don't say much, ask "Tell me about the content that you teach."

3. How does the content you teach help students prepare for life after high school?

4. What else do you teach that might help students prepare for life after high school?

a. E.g., routines, expectations, behaviors, goal setting

5. Is there anything else you do that might possibly prepare students for life after high school?

a. E.g., advise extracurricular, provide individual support on careers or colleges 6. Now, let's talk specifically about students with disabilities. How does your role preparing students with disabilities for adult life compare to your general role with all your students?

a. How is it similar?

b. How is it different?

c. Follow-up questions based on responses to previous questions

7. Describe how you have been involved in transition plans for your students with disabilities for life after high school?

a. E.g., reference IEP

8. What if any support would you like to have related to your involvement in preparing students with disabilities for life after high school? 
9. Is there anything else you want to tell me about preparing students with and without disabilities for life after high school? 